GABRIEL FRANCO DA ROSA LOPES

\title{
A JUSTIÇA DO CONFLITO: POLÍTICAS JUDICIÁRIAS DE CONCILIAÇÃO TRABALHISTA NO BRASIL
}

Tese de Doutorado

Orientador: Professor Jorge Luiz Souto Maior

UNIVERSIDADE DE SÃO PAULO

FACULDADE DE DIREITO

São Paulo - SP 
Gabriel Franco da Rosa Lopes

\section{A JUSTIÇA DO CONFLITO: POLÍTICAS JUDICIÁRIAS DE CONCILIAÇÃO TRABALHISTA NO BRASIL}

Tese apresentada à Banca Examinadora do Programa de Pós-Graduação em Direito, da Faculdade de Direito da Universidade de São Paulo, como exigência parcial para obtenção de título de Doutor em Direito, na área de concentração de direito do trabalho e da Seguridade Social, sob a orientação do Professor Associado Jorge Luiz Souto Maior

\section{UNIVERSIDADE DE SÃO PAULO}

\section{FACULDADE DE DIREITO}

São Paulo - SP 
Autorizo a reprodução e divulgação total e parcial deste trabalho, por qualquer meio convencional ou eletrônico, para fins de estudo e pesquisa, desde que citada a fonte.

\author{
Catalogação da Publicação
}

Serviço de Biblioteca e Digitalização

Faculdade de Direito da Universidade de São Paulo

Lopes, Gabriel Franco da Rosa

A justiça do conflito: políticas judiciárias de conciliação trabalhista no Brasil / Gabriel Franco da Rosa Lopes; orientador Jorge Luiz Souto Maior - São Paulo, 2019.

$176 \mathrm{f}$.

Tese (Doutorado - Programa de Pós-Graduação em Direito do Trabalho e Seguridade Social) - Faculdade de Direito, Universidade de São Paulo, 2019.

1. Políticas judiciárias de conciliação; 2. Justiça do Trabalho; 3. Neoliberalismo. 


\section{SUMÁRIO}

\section{AGRADECIMENTOS}

INTRODUÇÃO

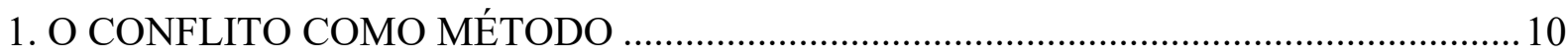

1.1 DA DIVISÃO SOCIAL DO TRABALHO AO DIREITO DO TRABALHO ................... 19

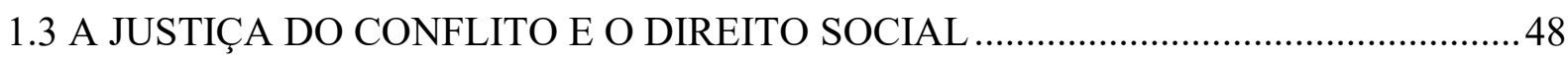

2. A JUSTIÇA DO TRABALHO EM SEU CONTEXTO $(2004$ - 2016) ............................... 50

2.1 A GÊNESE DO NEOLIBERALISMO E OS ANTECEDENTES HISTÓRICOS ............51

2.1.1 O FIM DA EXPANSÃO CAPITALISTA DO PÓS-GUERRA E A SOLUÇÃO

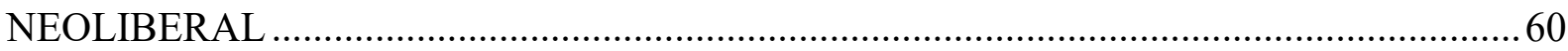

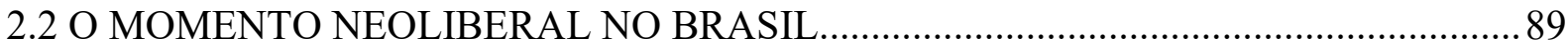

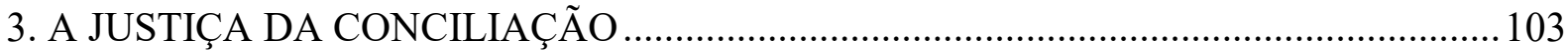

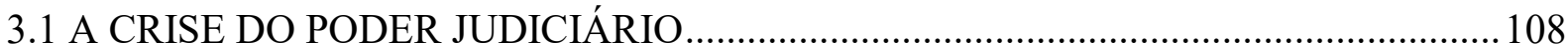

3.2 O CONSELHO NACIONAL DE JUSTIÇA E O CONSELHO SUPERIOR DA JUSTIÇA

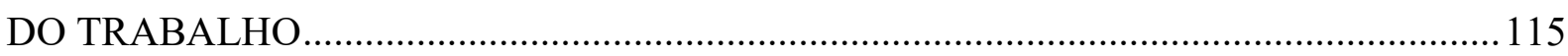

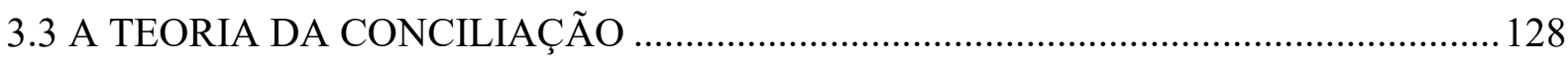

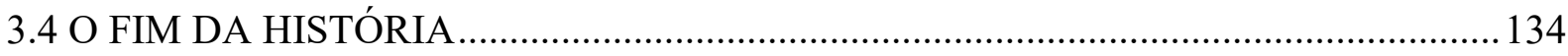

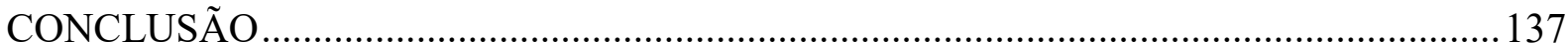

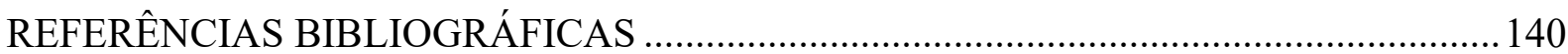

REFERÊNCIAS SOBRE CONCILIAÇÃO E POLÍTICAS JUDICIÁRIAS DE

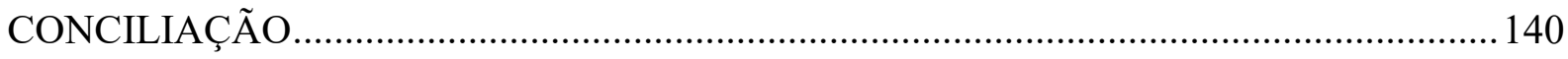

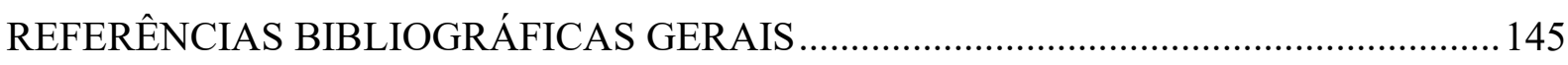




\section{AGRADECIMENTOS}

Inicialmente, a presente pesquisa reverencia a toda a tradição crítica do pensamento social a que se vincula. Mesmo os desenvolvimentos teóricos de maior autenticidade deste trabalho são indissociáveis desta herança intelectual. A elaboração desta tese não seria possível sem o acesso à obra de Antonio Gramsci ou aos textos de Francisco de Oliveira. Entretanto, ante a impossibilidade de se reduzir uma produção teórica cuja envergadura se confunde com a própria história ao brevíssimo espaço destinado, o primeiro dos agradecimentos é endereçado aos autores, referenciados ou não, que comprometeram seu trabalho intelectual com uma mudança social voltada à emancipação humana. Em acréscimo a estes agradecimentos, de perspectiva distinta, referencia-se a toda a tradição política, no interior da qual estas teorias se inserem, e de onde retiram sua razão de ser. Em síntese, àqueles que optaram e se empenhar, em uma luta por outra sociedade.

Um segundo agradecimento, cujo cerne da presente pesquisa exige que se mencione, é a todos os trabalhadores e trabalhadoras que rompendo com o temor reverencial a que são condicionados disseram "não", erguendo sua recusa contra a autoridade do patrão ou do Estado, individual ou coletivamente, por meio de greves ou pelo gesto sútil, embora muitas vezes de coragem, de se ingressar com uma reclamação trabalhista. Em cada ato de enfrentamento dos oprimidos, reside o gérmen de um mundo melhor e mais justo, pois da luta contra a opressão e exploração que surge a esperança.

Neste sentido, é imprescindível um enfático agradecimento a meu orientador, o Professor Jorge Luiz Souto Maior, com quem tive o privilégio de poder conviver durante a realização desta pesquisa. Ao lado deste grande lutador, pude compreender a importância da coerência, onde o pensamento e a ação se traduzem reciprocamente.

Juntamente, agradeço à minha esposa e companheira, Ingrid, a qual deu suporte a toda a trajetória acadêmica que percorri desde o mestrado, especialmente em seus momentos mais difíceis, dividindo angústias e alegrias, vitórias e derrotas e, acima de tudo, com quem compartilho os sonhos que no guiam, nesta noite fria, mas estrelada, que é a existência. 
Agradeço aos meus pais, Ailton e Elizabeth e ao meu irmão Matheus, pelo apoio e compreensão em todo o processo da pesquisa.

Fundamental mencionar ainda, alguns dos muitos amigos e amigas, sem os quais, também esta pesquisa não existiria. Agradeço enfaticamente meus amigos Ana Navarrete, Gustavo Angelleli, Paulo Yamamoto e Raphael Ferreira, com quem pude aproveitar alguns dos melhores momentos de toda a minha trajetória no mestrado e doutorado, e que tornaram o percurso muito mais agradável. Agradeço ainda os amigos que vieram por meio da advocacia, José Carlos Callegari, Mariana Salinas e João Guilherme; os camaradas, Victor Vilela e Thais; os amigos e companheiros, Ana Lúcia Marchiori e Edu Pizza; os novos amigos, Clarissa Viana, Deni Rubbo, Renan Kalil, e Tainã Góes; os professores Thiago Barison e Danilo Uler, companheiros de luta; e os camaradas, Flávio Bezerra e Flávia Maria.

Agradeço aos companheiros e companheiras do Sindicato dos Advogados de São Paulo, que participaram dos mandatos de Aldimar de Assis e Fábio Gaspar e aos lutadores e lutadoras da Intersindical, na figura de Cordeiro, Edilson e Índio. Agradeço ainda, aos empregados e empregadas do Sindicato dos Médicos, especialmente os membros da Comissão dos Empregados.

Por fim, um especial agradecimento aos professores Gustavo Seferian e Ruy Braga, com grande admiração, especialmente pela generosidade e pelas sugestões dadas quando do Exame de Qualificação. 
Aos que lutam por um mundo onde sejamos socialmente iguais, humanamente diferentes e totalmente livres. 
Gabriel Franco da Rosa Lopes. A justiça do conflito: políticas judiciárias de conciliação trabalhista no Brasil. 2019. 176 fl. Doutorado - Faculdade de Direito, Universidade de São Paulo, São Paulo, 2019.

\section{RESUMO}

A presente pesquisa investiga as políticas judiciárias de conciliação, na Justiça do Trabalho, entre 2004 e 2016, a partir dos conceitos de ideologia, burocracia e aparelho, a fim de compreender o processo de adequação desta ao neoliberalismo, entendido, por sua vez, como um momento das relações sociais. Abordado pelos elementos da exacerbação da competitividade, acento no indivíduo e de uma concepção de mundo organizada sob o horizonte de uma difusa teoria do fim da história, o neoliberalismo exibe uma relação de afinidade com a burocracia, de tal forma que, as políticas judiciárias de conciliação extraem sua coerência de um senso comum forjado diante da manutenção do sistema hegemônico, em um processo que, todavia, se caracteriza por um acúmulo de contradições.

\section{PALAVRAS CHAVE}

Políticas judiciárias de conciliação; Justiça do Trabalho; Neoliberalismo. 
Gabriel Franco da Rosa Lopes. The justice of the conflict: judicial policies of labor conciliation in Brazil. 2019. 176 pg. Doctorate - Faculty of Law, University of São Paulo, São Paulo, 2019.

\begin{abstract}
The present research examine the Judicial Policies of Conciliation, in the Labor Justice, between 2004 and 2016, from the concepts of ideology, bureaucracy and apparatus, in order to understand the process of its adaptation to neoliberalism, understood, in turn, as a moment of social relations. Faced with the elements of the exacerbation of competitiveness, an accent on the individual and a conception of the world organized under the horizon of a diffuse theory of the end of history, neoliberalism exhibits a relation of affinity with the bureaucracy, in such a way that the Judicial Policies of Conciliation draws its coherence from a common sense forged in the maintenance of the hegemonic system, in a process that, however, is characterized by an accumulation of contradictions.,
\end{abstract}

\title{
KEYWORDS
}

Judicial Policies of Conciliation; Labor Justice; Neoliberalism 
Ai, Santo Deus!

Vai começar!

Duas revoluções já não bastam?

Senhores, camaradas,

Que escândalo mais sem razão!

Vocês não têm outro caldo para refogar, não?

E vocês aí, acham que são os bons?

Encontraram a torta!

Olha aqui, venerado diabo,

Chega de briguinhas,

É preciso reconciliação.

(...)

Meus senhores!

Onde está a justiça

A gente quer a conciliação,

E eles me dão um pesçoção.

(Trecho da peça Mistério-bufo, de Vladímir Maiakóvski) 



\section{INTRODUÇÃO}

No ano de 2016, na Justiça do Trabalho, foram recebidos 2.756.214 novos processos, com um aumento de 4,5\% em relação ao ano de 2015 , tendo sido "solucionados"1 em primeiro grau 2.687.198 processos, com um saldo remanescente de apenas $2,5 \%$ e, pendendo o julgamento de 1.842 .918 processos $^{2}$. Por sua vez, embora tenham sido iniciadas 724.491 execuções (cerca de 26\% dos processos recebidos), bem como, tenham sido encerradas 661.850, permanece um saldo remanescente de 2.518.737 execuções. Deste modo, ainda que seja considerada alta a soma de R\$ 24.358.563.330,73, pagos em 2016, bem como, de R\$3.230.252.212,30 arrecadados em 2016, entre custas processuais, emolumentos, contribuição previdenciárias, imposto de renda e multas a aplicadas por órgãos de fiscalização, permanece um saldo ainda maior não pago e arrecadado. O valor orçamentário previsto pela LOA (Lei $n^{\circ} 13.255$, de 2016), R\$ 17.126.685.840,00, amortizado pelo valor arrecadado, seria ainda de $\mathrm{R} \$$ 10.462.129.703,03 menor que o pago, o que atesta que, mesmo com alto índice de inadimplemento, o valor gasto reverteria em uma quantia superior.

Analisados isoladamente, portanto, os dados parecem não apenas invalidar a tese de que a Justiça do Trabalho seria supostamente ineficiente, como também, que seria custosa. Cumpre ainda destacar, neste sentido, que a parcela destinada à Justiça do Trabalho apresentou uma queda proporcional à integralidade do orçamento fiscal nos anos de 2015 e 2016, a qual, ainda que pequena, representou um sufocamento orçamentário, considerado o volume proporcional previamente destinado à despesa com pessoal $^{3}$ e o aumento do número de ações no biênio ${ }^{4}$. Todavia, tal raciocínio afasta talvez o principal aspecto da Justiça do Trabalho, pois, deixa de avaliar o que os

\footnotetext{
${ }^{1}$ Adota-se a nomenclatura utilizada pelo próprio relatório, de modo a delimitar com o uso das aspas "solução" como uma determinada resposta do Estado, ao acesso à jurisdição, em primeiro grau, a qual irá implicar na extinção, improcedência, procedência em partes, procedência ou homologação de conciliação. 2 Dados disponíveis em: http://www.tst.jus.br/documents/10157/21fca4b3-524b-4bc0-bdc3b7641d7c83a8, consultados em 26/06/2017.

3 Considerando o Justiça em Números de 2015, de um total de orçamento destinado de $\mathrm{R} \$ 16.676 .696 .355,00$, um montante de $\mathrm{R} \$ 13.619 .309 .989,00$ era originalmente destinados à despesa com pessoal, o que, por exemplo confronta com o caso limítrofe da justiça federal cujo orçamento no referido ano, embora totalizasse R\$ $10.192 .650 .978,00$, destinava para estes gastos o valor de $\mathrm{R} \$$ 7.649.358.549,00.

${ }^{4}$ Em 2013 foram recebidas 2.132.220 ações em primeiro grau, em fase de conhecimento, e 2.365.547, em 2014, de modo que, em 2015, há um aumento para 2.659.007 e, em 2016, para 2.765.214. Dados disponíveis em http://www.tst.jus.br/web/guest/fase-de-conhecimento, consultados em 26/06/2017.
} 
processualistas denominam, a partir da transposição de um conceito utilizado para analisar o funcionamento dos mercados, "demanda contida" .

Isto porque, tal como se pode notar, dentre os dez assuntos mais demandados no Judiciário Trabalhista, em 2016, sete eram decorrentes de verbas rescisórias, além do pagamento incorreto de horas extras, do adicional de insalubridade e não concessão do intervalo intrajornada ${ }^{6}$. Note-se que, os dados do Relatório Justiça em Números, do $\mathrm{CNJ}^{7}$ referentes ao ano de 2015, indicavam que as verbas rescisórias ou decorrentes de rescisão contratual, não apenas eram as mais demandadas, totalizando $11,75 \%$ de todas as ações do Poder Judiciário, como eram superiores ao segundo e terceiro assunto mais demandado juntos, que são ações obrigações e contratos e de dívida ativa e, pouco menos do que somados ao segundo e terceiro assuntos mais demandados o quarto, que corresponde às ações requerendo responsabilização de fornecedor e indenização por dano moral consumeristas. A estes dados, deve ser acrescentado também o fato de que pouquíssimas ações na Justiça do Trabalho versam sobre contratos de trabalho em vigor, tais como, ações voltadas a obrigações de fazer ou não fazer e eventuais tutelas, mesmo no âmbito coletivo, além do número não irrelevante de 45.696, ações não julgadas em primeiro grau até 31 de maio de 2017, sobre "desconfiguração de justa causa" ${ }^{\circ}$.

Resta ainda notável o fato de que, considerado o terceiro trimestre de 2015, a Pesquisa Nacional de Domicílios do IBGE $^{9}$ aponta um número de 35.403 .000 empregos com carteira assinada, contra 39.227.000 sem carteira assinada, domésticos ou trabalhadores "por conta própria", de modo que, percebe-se não apenas um alto índice

\footnotetext{
${ }^{5} \mathrm{O}$ termo que se popularizou acriticamente entre os processualistas usualmente é atribuído a Kazuo Watanabe, que fala em litigiosidade contida. Note-se que, originalmente, a menção guarda referência a uma análise dos Juizados Especiais (Cf. WATANABE, Kazuo. Filosofia e características básicas do Juizado Especial de Pequenas Causas. In: WATANABE, Kazuo (Coord.), Juizados Especial de pequenas causas. São Paulo: Ed. Revista dos Tribunais, 1985, p. 2)

${ }^{6}$ Tais dados são praticamente idênticos se confrontados os casos novos recebidos entre janeiro e maio de 2017 (disponíveis em http://www.tst.jus.br/documents/10157/2ac40bb8-c47c-4471-8823-6f22759caa8c, $\begin{array}{lllllll}\text { consultados em 26/06/2017) com } & \text { o } & \text { acervo } & \text { (disponível em }\end{array}$ http://www.tst.jus.br/documents/10157/2ac40bb8-c47c-4471-8823-6f22759caa8c, consultado em $26 / 06 / 2017)$

7 Dados disponíveis em:

http://www.cnj.jus.br/files/conteudo/arquivo/2016/10/b8f46be3dbbff344931a933579915488.pdf, consultados em 26/06/2017.

8 Dados disponíveis em:

http://www.tst.jus.br/documents/10157/14391536/Pendentes+de+Baixa+por+Assunto+-+Dezembro+-

+ Ano+2016+-+1\%C2\%BA+Grau.pdf/d63e678a-9f78-0ad4-63f0-9ba54ed5bd16, consultados em $26 / 06 / 2017$.

Disponível

em

http://www.ibge.gov.br/home/estatistica/pesquisas/pesquisa resultados.php?id pesquisa=40, consultada em 26/06/2017.
} 
de informalidade ${ }^{10}$, como, se cotejados tais dados com o número de 2.659.007, recebidas em primeiro grau em 2015, as ações representam apenas cerca de 3,5\%, dos trabalhadores, de modo que, considerando-se ainda, os assuntos demandados, não é possível afirmar que há um alto índice de litigiosidade, ao contrário, o que se verifica é um altíssimo potencial de novas ações.

Tais informações permitem que se identifique que o descumprimento legal não se trata de algo acidental ou contingente no Brasil, mas de um dado presente na relação entre capital e trabalho, o que Adalberto Cardoso nomeia deslegitimação do direito do trabalho dentre os empregadores ${ }^{11}$, de tal forma que o papel pedagógico do direito ${ }^{12}$, no interior do sistema hegemônico, se torna um elemento de perpetuação de relações precárias. Com isso, inverte-se a conclusão concernente à eficiência da Justiça do Trabalho se considerado como parâmetro principal o uso da coerção e eventualmente a força para dar efetividade aos dispositivos materiais ${ }^{13}$

Neste contexto, um dos elementos centrais é o altíssimo índice de conciliação de litígios na Justiça do Trabalho, que em 2016 foi de 38,8\% do total de processos resolvidos em primeiro grau. No Tribunal Regional do Trabalho da $2^{\mathrm{a}}$ Região $^{14}$, responsável pela região metropolitana de São Paulo e Baixada Santista, se em 2016 foram recebidos 93.669 processos e solucionados 86.446, destes, 43,5\% foram conciliados, 26,9\% julgados parcialmente procedentes, 8,4\% improcedentes, 1,5\% procedentes, de modo que, a conciliação representa um mecanismo de importância central para a Administração Judiciária. Em termos monetários, o valor pago em processos conciliados em fase de conhecimento totalizou em 2016, R\$ 1.117.300.674,80, do total de $\mathrm{R} \$ 5.832 .327 .245,43$ em valores pagos. A comparação entre os $43,5 \%$ conciliados e os cerca de $19 \%$, dos valores pagos, ainda que em termos

\footnotetext{
${ }^{10}$ Importante destacar que, o número de pessoas que possui empresa constituída, ainda que para a perpetração de fraude trabalhista, é bastante baixo, em aproximadamente 7,5 milhões, o que não invalida a tese da alta informalidade.

${ }^{11}$ A tese está presente em dois textos, essenciais para a compreensão da atual configuração da Justiça do Trabalho. Cf. CARDOSO, Adalberto. " direito do trabalho e relações de classe no Brasil: revisitando problemas e interpretações", In: A década neoliberal: e a crise dos sindicatos no Brasil, São Paulo: Boitempo, 2003, p. 123-204 e CARDOSO, Adalberto e LAGE, Telma. "Desenho e desempenho do sistema de vigilância e aplicação das normas trabalhistas" e "Desenho e desempenho da Justiça do Trabalho", In: As normas e os fatos: desenho e efetividade das instituições de regulação do mercado de trabalho no Brasil, Rio de Janeiro: Editora FGV, 2007, pp. 71-130)

${ }^{12}$ Entende-se como papel pedagógico do direito, o sentido atribuído por Antonio Gramsci, Cf. BIANCHI, Alvaro. O laboratório de Gramsci: filosofia, história e política, São Paulo: Alameda, 2008, pp. 192-198.

${ }^{13}$ Não se pode deixar de notar que há uma enorme atrofia no que tange à atuação coletiva, o que poderia vir a resolver os assuntos mais demandados, todavia, tais procedimentos enfrentam uma enorme resistência por parte do judiciário de primeiro grau, o que poderia vir a ser objeto de outra pesquisa.

${ }_{14}$ Disponível em http://www.trtsp.jus.br/images/Transparencia/Estatistica/publicacoes-epesquisas/2016.pdf, consultado em 26/06/2017.
} 
aproximados, atesta que os valores das conciliações tendem a ser consideravelmente inferiores aos valores pagos em processos com resolução adjudicada.

Igualmente, é importante notar que, a conciliação judicial, durante todo o período contabilizado em dados estatísticos, é o principal solucionador de ações trabalhistas ${ }^{15}$, cujas variações desde $2004^{16}$, marco da atual configuração da Justiça do Trabalho, com a Emenda Constitucional 45, de 2004, de 44,1\% a 38,8\% em $2016^{17}$, fator este que deve ser confrontado com o aumento de processos ${ }^{18}$, de 1.607.163 inicialmente recebidos em 2004, para 2.756.214 em 2016. Ou seja, a conciliação, não apenas não retraiu como representa um fenômeno ainda mais intenso considerada a ampliação da Justiça do Trabalho.

Todavia, se a conciliação judicial enquanto "solucionadora de litígios" representa um dado constante na história da Justiça do Trabalho, indaga-se o porquê de toda a inflexão sobre a importância de uma Política Judiciária Nacional de Tratamento Adequado das Disputas de Interesses, como o objeto da Resolução do Conselho Superior da Justiça do Trabalho, de $\mathrm{n}^{\circ} 174$, de 2016, que decorre de todo o movimento que se amplia desde 2004, com a Emenda Constitucional no 45 , a qual também criou o Conselho Nacional de Justiça?

Cumpre notar que não se trata apenas de um incentivo às conciliações, mas de todo um enorme esforço, que passa pela criação de premiações, como o "Conciliar é Legal", adoção de uma agenda especialmente destinada para isso, como a "Semana da Conciliação", e com a criação de "Núcleo Permanente de Métodos Consensuais de Solução de Conflitos", tudo isso, com uma configuração claramente importada do "Movimento pela Conciliação" de origem Processual Civil ${ }^{19}$, com um conjunto de termos adaptados.

\footnotetext{
15 Note-se que os dados entre 1980 e 2016, revelam números razoavelmente estáveis a respeito da conciliação. A década de 1980, a qual se inicia com um número de ações muito inferior ao atual patamar, com 748.985 de ações recebidas nos três graus de jurisdição e 49,7\% de ações conciliadas, irá sofrer o início de um processo de aumento exponencial do número de processos, a partir de 1988, quando se nota uma queda sútil do número de conciliações para o patamar de 45,7\%, todavia, com um aumento substancial no número de conciliações. A queda seguinte, também muito sútil, ocorrerá somente em 2013, com o percentual de conciliações, caindo para a média de 39,5\%, nos quatro anos entre 2013 e 2016 , novamente acompanhado por um aumento do número de ações, o qual se inicia ainda em 2012.

${ }^{16}$ Marco da atual configuração da Justiça do Trabalho, conforme a presente pesquisa, decorrente da Emenda Constitucional 45, de 2004.

${ }^{17}$ Disponível em http://www.tst.jus.br/web/guest/conciliacoes1, consultado em 26/06/2017.

${ }^{18}$ Disponível em http://www.tst.jus.br/web/guest/fase-de-conhecimento, consultado em 26/06/2017.

${ }^{19}$ Não por outro motivo, a maior parte das compilações de artigos destinadas ao tema abrangem todo o Poder Judiciário: cf. PELUSO, Antonio Cezar e RICHA, Morgana de Almeida. Conciliação e mediação: estruturação da política nacional, Rio de Janeiro: Editora Forense, 2008 e GUNTHER, Luiz Eduardo e
} 
Ainda na continuação da dúvida proposta, se a ineficácia da legislação e a conciliação são dados continuamente presentes, não seria salutar destinar atenção e verbas à tentativa de fazer valer os Direitos Sociais, o que inclusive poderia vir a resultar no aumento dos valores pagos e arrecadados e a diminuição do número de ações? Ou seja, por que destinar uma atenção excessiva ao tema da conciliação quando não apenas este não resolve os problemas do Judiciário trabalhista como parece acentuá-los?

Da mesma forma, considerando que a principal bibliografia utilizada quando se trata deste tipo de política, o relatório de Bryant Garth e Mauro Cappelletti, Acesso à Justiça $^{20}$, estabelece três ondas no movimento de acesso, muito sinteticamente entendidas pela assistência judiciária, pela representação de interesses coletiva e o acesso à justiça como enfoque (momento este no qual as soluções não adjudicadas estariam presentes), tal modelo seria compatível com a formação da Justiça do Trabalho brasileira, inclusive por conta da já mencionada tendência à conciliação e do parco sistema de atendimento a demandas coletivas? Quais motivos conduziriam à interpretação enviesada da obra?

Tais indagações, não devem ser apartadas de outro paradoxo presente na Justiça do Trabalho: os direitos por ela "tutelados", embora usualmente sonegados, e cuja reparação, muitas das vezes é resolvida mediante transações de cariz inequivocamente mercantil, em valores inferiores aqueles decorrentes do cumprimento da lei, os próprios Juristas denominam irrenunciáveis ${ }^{21}$. Inclusive por este motivo, é importante frisar a existência de uma contratendência, a qual embora não seja o objeto imediato da presente pesquisa, pode ser exemplificativamente encontrada na nega a utilização de Mandados de Segurança contra decisão que não homologa acordo, consubstanciada a partir de precedentes obtidos em julgados entre 1993 e 2001, nas Orientações Jurisprudenciais da Subseção Especializada em Dissídios Individuais do Tribunal Superior do Trabalho (SBDI-2) números 120, de 2003 e 141, de 2004. Em suma, não se trata de um movimento harmônico ou homogêneo e que, inclusive, ele próprio engendra iniciativas

PIMPÃO, Rosemarie Diedrichs. Conciliação um caminho para a paz social, Curitiba: Juruá Editora, 2013.

${ }^{20}$ CAPPELLETTI, Mauro e GARTH, Bryant. Acesso à Justiça, tradução de Ellen Gracie Northfleet, São Paulo: Sergio Antonio Fabris Editor, 1988 (reimpressão de 2015).

${ }^{21}$ Tal fator é importante frisar, ainda que se reconheça a operação doutrinária que aparta a figura jurídica da "renúncia" destas transações feitas judicialmente, o que ao ver deste pesquisador, demonstra inclusive o modo como o senso comum dos juristas, ao fim e ao cabo, sob a justificativa da razoabilidade, sacrifica sua "lógica" ou "racionalidade" a luz de necessidades pragmáticas, principalmente demandadas por atritos decorrentes da relação dialética entre estrutura e superestrutura. 
contrárias, ainda que de menor dimensão, considerado o peso institucional de tais políticas.

Contudo, observado o processo de emergência da Resolução $n^{0}$ 174, de 2016, do Conselho Superior da Justiça do Trabalho (CSJT), a luz das mudanças institucionais ocorridas entre a Emenda Constitucional (EC) n² 28, de 1999, a qual extinguiu os Juízes Classistas, bem como, da $\mathrm{EC}^{\mathrm{o}}$ 45, de 2004, fruto de um movimento de reforma do Poder Judiciário, a qual cria o Conselho Nacional de Justiça (CNJ), nota-se um movimento tendencial de mudança da Justiça do Trabalho, a qual se adequa à racionalidade neoliberal. Embora tais mudanças estejam presentes em todo o Poder Judiciário, a Justiça do Trabalho merece um especial tratamento posto sua pretensão de versar (ainda que parcialmente) sobre o conflito social fundamental que caracteriza o modo de produção capitalista ou a forma por meio da qual a riqueza é produzida a partir de determinadas relações sociais. Sob o pano de fundo destas mudanças, como se pretende destacar, está uma relação de afinidade existente entre a burocracia responsável pela elaboração e difusão (também enquanto ato de disputa) do direito do trabalho e a racionalidade neoliberal, que aponta para uma determinada forma de se compreender e vivenciar a história, a qual esvazia o potencial transformador do conflito entre as classes sociais fundamentais, considerando-o como meros perturbadores da ordem.

Isto porque, tal como o abordado na primeira parte da pesquisa, a formação do Poder Judiciário Trabalhista demanda a elaboração de um conjunto de intelectuais, responsáveis pela elaboração e difusão de uma ideologia, compreendida como forma de compreensão do conflito social fundamental mediada pela forma jurídica. Estes intelectuais tomam a forma de uma burocracia, pois não apenas ocupam um lugar na formação do consenso, ou do sistema hegemônico, como esta se dá pelo uso potencial do aparato coercitivo como forma de produzir consentimento. O direito do trabalho, enquanto forma de se tentar compreender o conflito entre as classes sociais fundamentais, todavia, o faz a partir da estrutura formal do mercado, presumindo uma assimetria genérica entre as partes como mecanismo de garantir a manutenção da igualdade jurídica. De outra sorte, constata-se que esta contradição, que é a natureza da Direito Social, está no centro do direito do trabalho, o que torna este objeto de permanente disputa no conflito entre as classes sociais fundamentais. A partir destes três elementos fundamentais: uma ideologia, uma burocracia e um aparelho hegemônico, é possível perceber que a autonomia tomada pelo direito do trabalho, centrada em uma 
presunção de assimetria, dá-se em um processo por meio do qual se engendram contínuas contradições.

Estes elementos que aparecem de forma combinada no processo social exibem uma importante relação quando observado o fenômeno histórico do surgimento da Justiça do Trabalho, tendo em vista que esta desponta entre 1930 e 1946, em um projeto de acumulação industrial. A própria ausência de efetividade da legislação enquanto dado histórico ocupa um lugar de fundamental importância na manutenção do sistema hegemônico. Em especial, deve ser observado o modo como o conflito social fundamental, o conflito de classes, é apreendido por meio de uma mediação com a forma jurídica, naquilo que se denomina litígio judicial. Uma vez captado o conflito pelo litígio, esvazia-se seu caráter transformador, visto que, este passa a ser tacitamente considerado um distúrbio não desejado, fruto de um dado imutável, a divisão entre classes sociais engendrada pela configuração do mundo produtivo. $\mathrm{O}$ resultado disso é que a estrutura obrigacional do direito do trabalho, considerado aqui o direito individual, expressa uma forma de se compreender a história, esvaziada sua dimensão dialética, ou seja, considerando as relações sociais capitalistas como definitivas.

Em que pese o capitalismo seja uma continuidade no processo histórico, enquanto suporte real da superestrutura jurídica, este se dá na descontinuidade imposta pelo neoliberalismo, enquanto momento posterior ao final da década de 1960, quando por uma atuação de classe, especialmente dirigida pelas frações do capital financeiro, fruto de uma crise de acumulação, inicia um período de intensificação da espoliação. Mais do que isso, o neoliberalismo impõe a concorrência enquanto critério ético, impelindo a padrões predatórios de concorrência, centrados especialmente no indivíduo enquanto local de realização da liberdade. Para além, o que se nota do neoliberalismo é uma concepção própria do conflito social, o qual tendencialmente recebe o sinal positivo, sendo ele desejável e o aumento da competição algo que favorece a seleção pelo mérito. Esta mudança tem como pano de fundo outra, de ainda maior relevância, uma concepção difusa de fim da história, a qual se caracteriza pela percepção de que o horizonte capitalista e suas instituições são um dado definitivo da história.

No Brasil, em que pese a adoção das "políticas neoliberais" se inicie com o governo de Fernando Collor, sua difusão e consolidação do neoliberalismo somente serão possíveis nos governos de Fernando Henrique Cardoso e Luiz Inácio Lula da Silva. Tais mudanças estão presentes não apenas nas sucessivas modificações legislativas, como no processo de precarização que corre à margem da legislação social, 
graças à enorme informalidade. Estas relações precárias são funcionalizadas pelo capital, com vistas a garantirem permanentes processos de acumulação primitiva, baseados no uso potencial da violência. Note-se que, se a violência instaura a ordem capitalista, disciplinando a força de trabalho, o uso desta é sempre potencial caso haja riscos a estas relações.

Dentre as mudanças institucionais ocorridas durante o período neoliberal, o estabelecimento do Conselho Nacional de Justiça, e uma política fundamentada no uso de critérios quantitativos para a gestão do Poder Judiciário, marcam um deslocamento importante. Entendido como um fornecedor de uma espécie de "serviço jurisdicional", medido pela baixa de ações, o Poder Judiciário tendencialmente passa a utilizar critérios de avaliação cuja racionalidade remete ao mercado, mesmo que inequivocamente este não possua qualquer caráter produtivo. Se no plano teórico a mudança se justifica pela alteração do conceito de Acesso à justiça, a qual abarca a dimensão temporal enquanto elemento fundamental, sua atuação pretende, em grande medida, adequar a temporalidade do Poder Judiciário àquela imposta pela estrutura econômica ${ }^{22}$. Entre 2004 e 2016, um conjunto de políticas públicas é utilizado pelo CNJ e pelo Conselho Superior da Justiça do Trabalho - CSJT, tomando como norte uma permanente busca por maior eficiência temporal na prestação jurisdicional. Centralmente as mais importantes políticas públicas neoliberais, são aquelas destinadas ao fomento da conciliação, visto que, na Justiça do Trabalho, estas representam a maior parte das soluções dadas aos litígios judiciais. As conciliações repõem a forma contratual e são plenamente adequadas ao modo como o neoliberalismo vez que coroam o indivíduo como local de realização da liberdade por excelência. Igualmente, há que se destacar que a ideologia jurídica e o neoliberalismo, tendencialmente compreendem que as relações entre as classes sociais fundamentais, são um dado histórico definitivo. Todos estes elementos confluem para a participação profundamente contraditória da Justiça do Trabalho na manutenção das relações de classe no sistema hegemônico.

Tendo como marco final a emergência da Resolução no 174, de 2016, do CSJT, a presente pesquisa abarca o período histórico onde a hegemonia se exerceu através de governos caracterizados pela conciliação de classe, os governos Lula e Dilma, bem como, o início do colapso da "hegemonia lulista", que tal como neoliberalismo se caracteriza por uma atuação de classe destinada a promover mudanças predatórias,

\footnotetext{
${ }^{22}$ Como se verá a seguir, não se poderia deixar de destacar o caráter profundamente contraditório de tais mudanças, não devendo de forma alguma ser observadas unilateralmente.
} 
especialmente na legislação trabalhista. Com certo distanciamento, é possível perceber que o período entre 2004 e 2016, se insere no interregno entre duas reformas trabalhistas, voltadas à redução predatória do custo de reprodução da força de trabalho por meio da revogação de garantias legais.

Embora o caráter conciliatório produza efeitos desejáveis à manutenção do sistema hegemônico, não causa surpresa que o aumento do preço da força de trabalho, oriundo da parcial efetividade conferida à legislação social, coloquem-na em situação frágil diante do interesse imediato do capital. Inclusive por este motivo, justifica-se a adoção de um conjunto conceitual que se volta às relações de força, vez que, ao fim e ao cabo, são estas próprias que oferecem as condições de possibilidade de existência do direito do trabalho e a tentativa de torná-lo mais efetivo. Político por excelência, o direito do trabalho traz impresso em si próprio as contradições de uma sociedade que elabora a sociabilidade de seus indivíduos a partir de um conflito fundante. Entender o resultado deste confronto entre as classes sociais fundamentais, inclusive no interior do próprio aparelho hegemônico, é compreender, a partir deste, a própria sociedade.

Neste sentido, como se verá adiante, o interesse nas políticas judiciárias de conciliação, realizadas entre 2004 e 2016, reside justamente no modo como estas expressam a adequação do Judiciário Trabalhista ao neoliberalismo.

Ainda antes de dar início ao primeiro capítulo vale destacar que a presente pesquisa toma como ponto de vista o próprio devir histórico e suas contradições, o que implica dizer, o caráter histórico e, portanto, provisório da institucionalidade que se apresenta. Ao partir da premissa da possibilidade de superação da estrutura e superestrutura apresentadas, a presente pesquisa rompe com a concepção de mundo subjacente, que considera tais relações sociais como um dado histórico definitivo. Mesmo que hipoteticamente, o confronto social aponta para a necessidade de superação dessa relação de forças, o que inclusive estava estampado na fragilidade da última tentativa de garantir a conciliação de classes, feita pouco antes do impeachment de Dilma Rousseff. Mais do que entender a legislação social, é fundamental compreender qual o papel desempenhado pela institucionalidade responsável por sua efetivação, a fim de se compreender o impacto de suas contradições no devir histórico. 
Não por outro motivo, a Justiça do Trabalho, em seu cerne carrega estas duas faces: a justiça do conflito e a justiça da conciliação. A contradição entre capital e trabalho, que está na base do direito do trabalho, se desdobra na contradição entre a conciliação e o conflito. O próprio cerne do direito do trabalho, a contradição existente no reconhecimento da falsificação promovida pela igualdade formal e sua aplicação, apontam para um permanente conflito, diante do qual a burocracia permanece titubeante, observando que sua atuação está sempre em atrito com a organização do sistema hegemônico, mesmo que sendo parte importante dele. No cerne do direito social, o "direito" e o "social", parecem conviver em um permanente confronto, incapaz de ser resolvido dentro dos marcos onde ele próprio foi concebido. A concepção de fím da história, que naturaliza a divisão entre as classes sociais e seu confronto, direciona a burocracia a lutar contra o próprio devir histórico. Diferentemente do direito do trabalho, "a história nada sabe da má infinitude na imagem de dois combatentes eternamente lutando"437. No "fim da história", o início aparece inscrito, todavia, sem garantias.

\section{CONCLUSÃO}

A presente pesquisa foi inicialmente planejada em 2014, quando a ex-presidente Dilma Rousseff havia sido recém-eleita, em um processo bastante polarizado, tendo logo no primeiro momento demonstrado que operaria uma série de recuos, concretizados em um "ajuste fiscal”, cujo ministro responsável seria Joaquim Levy. Diante do fracasso da tentativa de se dar maior sobrevida à política de conciliação de classes que caracterizou os governos petistas, bem como, de um Poder Legislativo cuja

\footnotetext{
${ }^{437}$ BENJAMIN, Walter. Rua de mão única, tradução de Rubens Rodrigues Torres Filho e José Carlos Martins Barbosa, 6a ed., São Paulo: Editora Brasiliense, 2012, p. 46.
} 
composição tornava o governo bastante vulnerável, no fatídico dia 12 de maio de 2016, Dilma Rousseff é afastada em meio a um processo de impedimento inequivocamente político, dando início ao conturbado período de presidência de Michel Temer. Embora seu mandato tenha sido bastante turbulento, considerada sua altíssima impopularidade, Temer obtém a aprovação da mais grave mudança legislativa trabalhista da história brasileira, a "Reforma Trabalhista", de Lei no 13.467, de 2017, dando início a um período de profunda incerteza, seja quanto ao conteúdo da própria legislação, como quanto à existência da Justiça do Trabalho. Ao final de 2018, assiste-se ainda outro processo eleitoral, ainda mais polarizado e marcado pela prisão do candidato melhor colocado nas pesquisas, o ex-presidente Lula, e pelo uso sistemático de mídias digitais, com a difusão sistemática de notícias falsas (fake news), quando é eleito Jair Bolsonaro, candidato da extrema-direita que havia externado em várias ocasiões apreço à tortura, rechaço a minorias e, inclusive durante o processo eleitoral, ameaçado seu adversário Fernando Haddad. Ao final do período de conciliação de classes, portanto, uma grave crise de hegemonia conduz à direção do poder executivo um candidato que em diversos momentos manifestou-se contra a legislação trabalhista e a Justiça do Trabalho.

No breve lapso de elaboração, as intensas mudanças políticas ocorridas conduziram as relações entre trabalho e capital ao centro do processo em curso, o que se estampa na caracterização de um golpe trabalhista ${ }^{438}$. Se por um lado tais mudanças permitem a compreensão da fragilidade do lulismo, de outro lado, colocaram em dúvida, inclusive a pertinência da pesquisa, o que não poderia ser diferente, considerada sua própria historicidade. Todavia, há uma peculiaridade do "campo jurídico" que não pode ser negligenciada: a confusão entre o objeto da pesquisa e localização do pesquisador no mundo social, ou seja, toda pesquisa acaba sendo em alguma medida uma espécie de autoanálise. O presente pesquisador, a título de exemplo, esteve na Audiência Pública de 23 de junho de 2016, como representante do Sindicato dos Advogados de São Paulo, tecendo duras críticas à própria organização do Poder Judiciário. Se por um lado este tipo próprio de investigação participante garante um acesso privilegiado ao "objeto" (do qual o próprio pesquisador é parte), de outro, não é possível se omitir o risco de contaminação da pesquisa pela atuação política e profissional.

\footnotetext{
${ }^{438}$ SOUTO MAIOR, Jorge Luiz. Impactos do golpe trabalhista (a Lei n. 13.467/17), disponível em https://www.jorgesoutomaior.com/blog/impactos-do-golpe-trabalhista-a-lei-n-1346717, consultado em 13.01.2019.
} 
Contudo, considerado o conjunto das relações sociais, não há como se defender um local externo à sociedade para que esta possa ser observada. A forma encontrada para se esquivar de uma parcela destes problemas foi o uso de categorias que pretendem compreender o direito por meio das relações de força, ou seja, por meio do movimento social e da historicidade das formas sociais. Com isso, almejou-se superar os limites da consciência dos juristas, no que tange à concepção difusa de fim da história, servindo-se da premissa da historicidade das formas sociais, ou seja, da pressuposição da possibilidade do direito do trabalho se tornar obsoleto. Estabelecer como hipótese a possibilidade de superação destas relações sociais, longe de um devaneio academicista é, na verdade, a única forma de se evitar o fetiche de um Estado naturalizado e definitivo. Ao invés de se tentar resolver no plano teórico as contradições encontradas, a presente pesquisa se centrou e se erigiu sobre elas, apontando sua origem no próprio real.

O conjunto de contradições investigado, portanto, conduziu a presente pesquisa à sútil ambiguidade das conciliações trabalhistas, que mesmo representando o fracasso histórico do direito do trabalho, diante de sua burocracia, permitiu em alguma medida a ampliação do acesso à justiça, prejudicando a tentativa de se reduzir permanentemente o custo da força de trabalho. A adequação ao neoliberalismo, com isso, implicou em um acúmulo de contradições, o que demonstra que nem sempre os critérios elaborados a partir da racionalidade do capital são úteis à reprodução do Capital. Todavia, não há como se eximir a responsabilidade da burocracia trabalhista, a qual operou tal adequação.

A abordagem sobre a formação da Justiça do Trabalho, inclusive, demonstrou que a formação de uma burocracia própria atendia à tarefa de se garantir a manutenção de determinadas relações de poder. Todavia, como foi dito, o próprio direito do trabalho, enquanto ideologia, por se consolidar sobre o contraditório reconhecimento de uma assimetria insuperável nas relações sociais, feito por meio da forma mercantil, não permite que a burocracia atenda plenamente a função para a qual foi vocacionada. Neste sentido, posta para decidir entre o direito do trabalho e a manutenção de uma determinada ordem social, em regra a burocracia opta por adequar o primeiro ao segundo. Entretanto, também o caráter de Direito Social impele o direito do trabalho contra sua própria sistematicidade, ou seja, contra o direito, contraditoriamente. Com isso, esboçam-se linhas gerais sobre o papel do jurista dentro do movimento histórico do qual é parte, que ao invés de resolver as contradições adequando o direito do trabalho 
à miséria social, reduzindo-se a um mero gestor do conflito social a serviço da espoliação econômica, por força do caráter de Direito Social do direito do trabalho deveria conduzir tais contradições, garantindo que a coerência do direito do trabalho seja extraída da própria contradição de interesses entre trabalho e capital. A partir disso, a atuação da burocracia poderia tomar uma forma pedagógica, de não apenas tornar claros os limites do direito, como de contribuir para a superação das contradições das quais ela própria é parte. A resolução do conflito social fundamental, como os próprios juristas perceberam, não deve ser buscada nos Tribunais, mas nas potencialidades subjacentes ao próprio conflito. Talvez desta forma seja possível, inclusive, forjar um autêntico estado de paz.

\footnotetext{
"Na aspiração a um ser humano desinibido, estuante, criativo insinuou-se o fetichismo da mercadoria, que traz consigo na sociedade burguesa a inibição, a impotência e a esterilidade do sempre igual. O conceito de dinâmica, que serve de complemento à 'carência de história' burguesa, é elevado ao absoluto enquanto, sendo ele na verdade reflexo antropológico das leis da produção, na sociedade emancipada cumpriria confrontá-la à necessidade.

(...)

Quando a sociedade emancipada é pensada como emancipada justamente dessa totalidade tornam-se visiveis linhas de fuga que pouco têm em comum com o incremento da produção e suas transfigurações humanas.

(...)

Porventura a sociedade verdadeira venha a fartar-se do desenvolvimento $e$, por liberdade, deixe de aproveitar oportunidades, ao invés de ser levada a lançar-se compulsivamente sobre estrelas distantes. Uma humanidade que não conheça a necessidade talvez venha a se aperceber daquilo que havia de maniaco, de frustrado em todos os arranjos até então encontrados para esquivar-se da necessidade quando, junto com a riqueza, eles próprios exerciam a reprodução ampliada da sociedade.

(...)

Rien faire comme une bete, nada fazer boiando na água e fitando pacificamente o céu, 'tão somente ser, sem qualquer outra ordem ou cumprimento' poderia ocupar o lugar do processo, do fazer, do desempenhar, e nisso verdadeiramente cumprir a promessa da lógica dialética, de desembocar na sua origem. Conceito abstrato algum se achega tanto à utopia cumprida quanto o da paz eterna.",439
}

\section{REFERÊNCIAS BIBLIOGRÁFICAS}

\section{REFERÊNCIAS SOBRE CONCILIAÇÃO E POLÍTICAS JUDICIÁRIAS DE CONCILIAÇÃO}

\footnotetext{
${ }^{439}$ ADORNO, Theodor. Minima moralia: reflexões a paritr da vida lesada, tradução de Gabriel Cohn, Rio de Janeiro: Beco do Azougue, 2008, pp. 153-154.
} 
ALKMIM, Gustavo Tadeu. A mediação na justiça do trabalho e o novo Código de processo civil: uma impossibilidade. Revista do Tribunal Superior do Trabalho, São Paulo, SP, v. 82, n. 3, p. 245-256, jul./set. 2016.

ANDRADE, Dárcio Guimarães de. Técnicas de conciliações trabalhistas. Revista eletrônica [do] Tribunal Regional do Trabalho da $9^{\text {a }}$ Região, Curitiba, PR, v. 1, n. 9, p. 90-95, jul. 2012.

AZEVEDO, André Gomma. "Desafios do acesso à justiça ante o fortalecimento da autocomposição como política pública nacional", In: CEZAR PELUSO, Antônio; RICHA, Morgana de Almeida (coord.). Conciliação e mediação: estruturação da Política Judiciária Nacional. Rio de Janeiro: Forense, 2011.

BACELlAR, Rogerio Portugal. O Poder Judiciário e o Pardigma da guerra na solução dos conflitos, In: CEZAR PELUSO, Antônio; RICHA, Morgana de Almeida (coord.). Conciliação e mediação: estruturação da Política Judiciária Nacional. Rio de Janeiro: Forense, 2011

BUZZI, Marco Aurelio Gastaudi. "Movimento pela conciliação - um breve histórico", In: CEZAR PELUSO, Antônio; RICHA, Morgana de Almeida (coord.). Conciliação e mediação: estruturação da Política Judiciária Nacional. Rio de Janeiro: Forense, 2011.

CALMON, Petronio. Fundamentos da mediação e da conciliação, $3^{\mathrm{a}}$ ed., Brasília, DF: Gazeta Jurídica, 2015

CALSING, Maria de Assis; VIVEIROS, Carolina C. Salomão Leal de. Mediação e conciliação: o novo CPC e os conflitos trabalhistas. Revista eletrônica [do] Tribunal Regional do Trabalho da 9a Região, Curitiba, PR, v. 6, n. 55, p. 25-43, out./nov. 2016.

CAVALCANTI, Felipe Locke e COSTA, Adriene Domingues. "O conselho nacional de justiça e a política judiciária de tratamento de conflitos”, In: GUNTHER, Luiz Eduardo e PIMPÃO, Rosemarie Diedrichs. Conciliação um caminho para a paz social, Curitiba: Juruá Editora, 2013

DAIDONE, Decio Sebastião. Trabalho voluntário no núcleo de conciliação por um excorregedor e ex-presidente de Tribunal Regional. Revista do Tribunal Regional do Trabalho da $2^{\text {a }}$ Região, São Paulo, SP, n. 8, p. 57-61, 2011. 
DESTE, Jair Francisco. Relevância da conciliação na solução dos conflitos trabalhistas. Revista eletrônica: acórdãos, sentenças, ementas, artigos e informações, Porto Alegre, RS, v. 2, n. 20, p. 24-25, fev. 2006.

DUARTE, Bento Herculano. Conflitos de interesses e vantagens da mediação. Revista eletrônica [do] Tribunal Regional do Trabalho da $9^{\text {a }}$ Região, Curitiba, PR, v. 5, n. 53, p. 69-76, ago. 2016.

FARIAS, James Magno Araújo. Jurisdição e mediação: a atuação da justiça do trabalho para garantir a proteção dos direitos laborais e a possibilidade de mediação trabalhista no Brasil. Revista do Tribunal Superior do Trabalho, São Paulo, SP, v. 81, n. 2, p. 107-120, abr./jun. 2015.

FELICIANO, Guilherme Guimarães. Termo de conciliação nas Comissões de Conciliação Prévia: natureza jurídica e eficácia liberatória. Revista da Faculdade de Direito, Universidade de São Paulo, [S.1.], v. 97, p. 205-209, jan. 2002. ISSN 23188235. Disponível em: <http://www.revistas.usp.br/rfdusp/article/view/67541>. Acesso em: 08 Out. 2015. doi:http://dx.doi.org/10.11606/issn.2318-8235.v97i0p205-209

FILGUEIRAS, Vitor Araújo. A justiça do trabalho e a conciliação impossível $=$ The labor court and the impossible conciliation. Revista do Tribunal Regional do Trabalho da $15^{\text {a }}$ Região, Campinas, SP, n. 45, p. 89-114, jul./dez. 2014

FORTES, Olga Vishnevsky. Conciliação em fase de execução e acordo extrajudicial. Revista do Tribunal Regional do Trabalho da $2^{\text {a }}$ Região, São Paulo, SP, n. 6, p. 119$125,2010$.

GEMIGNANI, Tereza Aparecida Asta. Audiência prévia de conciliação na justiça do trabalho: um passo rumo a modernidade. Revista do Tribunal Regional do Trabalho da 15ª Região, Campinas, SP, n. 7, p. 79-81, jul./dez. 1995.

GROENINGA, Giselle Câmara. A contribuição da mediação interdisciplinar: um novo paradigma: para a conciliação. Revista do Tribunal Regional do Trabalho da $2^{\text {a }}$ Região, São Paulo, SP, n. 8, p. 63-70, 2011.

GUNTHER, Luiz Eduardo e PIMPÃO, Rosemarie Diedrichs. Conciliação um caminho para a paz social, Curitiba: Juruá Editora, 2013. 
HIRANO, Ana Farias. Acordos homologados pela Justiça do Trabalho: uma análise dos dissídios individuais na fase de conhecimento. 2009. Dissertação (Mestrado em Direito do Trabalho) - Faculdade de Direito, Universidade de São Paulo, São Paulo, 2009. Disponível em: <http://www.teses.usp.br/teses/disponiveis/2/2138/tde-13082009092724/>. Acesso em: 2015-10-06.

KOLleR, Carlos Eduardo; VILlATORE, Marco Antônio César. Conciliação no direito comparado e seus aspectos sociais e econômicos. Revista eletrônica [do] Tribunal Regional do Trabalho da $9^{\text {a }}$ Região, Curitiba, PR, v. 1, n. 7, p. 55-69, maio 2012 .

KOURY, Luiz Ronan Neves. Mediação e conciliação no novo Código de processo civil: seus desdobramentos no direito processual do trabalho. Revista do Tribunal Regional do Trabalho da $3^{\text {a }}$ Região, Belo Horizonte, MG, v. 60, n. 91, p. 179-189, jan./jun. 2015.

LEITE, Samuel Corrêa. Conciliar é preciso. Revista do Tribunal Regional do Trabalho da $15^{\text {a }}$ Região, Campinas, SP, n. 6, p. 55-56, jan./jun. 1995

MANDALOZZO, Silvana Souza Netto; MOREIRA, Dirceia; ORTH, Glaucia Mayara Niedermeyer. A conciliação no processo do trabalho: diálogos com a psicologia. Revista eletrônica [do] Tribunal Regional do Trabalho da $9^{\text {a }}$ Região, Curitiba, PR, v. 1, n. 7, p. 16-30, maio 2012.

MENEZES, Marcelo Paes. A "crise da justiça" e a mediação. Revista do Tribunal Regional do Trabalho da $3^{\text {a }}$ Região, Belo Horizonte, MG, v. 33, n. 63, p. 23-31, jan./jun. 2001.

. Sobre mediação, direito do trabalho e conflitos de "ódio, amor e dor". Revista do Tribunal Regional do Trabalho da $3^{\text {a }}$ Região, Belo Horizonte, MG, v. 32, n. 62, p. 205-212, jul./dez. 2000.

MORAES, Gisela Rodrigues Magalhães de Araújo e. Acordo na justiça do trabalho: justiça ou injustiça?. Revista do Tribunal Regional do Trabalho da $15^{\text {a }}$ Região, Campinas, SP, n. 6, p. 90-91, jan./jun. 1995. 
NALINI, José Renato. "Fabricar a cultura da paz", In In: Conciliação Judicial Individual e coletiva e formas extrajudiciais de solução dos conflitos trabalhistas, São Paulo: LTr, 2014.

NOBILE, Marieta Giannico de Coppio Siqueira. Mediar, conciliar, pacificar: um artigo pela pacificação. Revista eletrônica [do] Tribunal Regional do Trabalho da $9^{\text {a }}$ Região, Curitiba, PR, v. 5, n. 53, p. 84-92, ago. 2016.

. O resgate da conciliação: a construção de um novo paradigma. Revista eletrônica [do] Tribunal Regional do Trabalho da $9^{\text {a }}$ Região, Curitiba, PR, v. 1, n. 7, p. 44-54, maio 2012.

ORSINI, Adriana Goulart de Sena; MELLO, Ana Flávia Chaves Vaz de; AMARAL, Tayná Pereira. A conciliação como concretização do acesso à justiça. Revista do Tribunal Regional do Trabalho da $3^{\text {a }}$ Região, Belo Horizonte, MG, v. 53, n. 83, p. 4155, jan./jun. 2011.

PIMENTA, José Roberto Freire. A conciliação judicial na Justiça do trabalho após a Emenda constitucional n 24/99: aspectos de direito comparado e o novo papel do juiz do trabalho. Revista do Tribunal Regional do Trabalho da $3^{\text {a }}$ Região, Belo Horizonte, MG, v. 32, n. 62, p. 29-50, jul./dez. 2000.

. “A conciliação na esfera trabalhista - função, riscos e limites", In: Conciliação Judicial Individual e coletiva e formas extrajudiciais de solução dos conflitos trabalhistas, São Paulo: LTr, 2014.

PINHEIRO, Rogério Neiva. Jurisdição, conciliação, criatividade e evolução humana. Revista do Tribunal Regional do Trabalho da $10^{\mathrm{a}}$ Região, Brasília, DF, v. 15/18, n. 15/18, p. 137-139, 2006/2009.

SENA, Adriana Goulart de. Juízo conciliatório trabalhista. Revista do Tribunal Regional do Trabalho da $3^{\text {a }}$ Região, Belo Horizonte, MG, v. 45, n. 75, p. 139-161, jan./jun. 2007.

SILVA, José Antônio Ribeiro de Oliveira. O acordo no processo do trabalho. Revista do Tribunal Regional do Trabalho da $15^{\text {a }}$ Região, Campinas, SP, n. 13, p. 155-166, out./dez. 2000. 
SILVA, Pedro Victor Vilas Boas da. Uma análise crítica da conciliação nos dissídios individuais do trabalho. Revista do Tribunal Superior do Trabalho, São Paulo, SP, v. 81, n. 2, p. 166-186, abr./jun. 2015.

SOUTO MAIOR, Jorge Luiz. Efeitos da Emenda constitucional n. $24 / 99$ e as armadilhas das recentes reformas trabalhistas. Revista do Tribunal Regional do Trabalho da $15^{\text {a }}$ Região, Campinas, SP, n. 11, p. 41-46, abr./jun. 2000.

.Os modos extrajudiciais de solução dos conflitos individuais do trabalho. Revista do Tribunal Regional do Trabalho da $15^{\text {a }}$ Região, Campinas, SP, n. 18, p. 16-49, jan./mar. 2002.

TOLEDO, Patrícia Therezinha de. Os conflitos trabalhistas e a importância dos sistemas de solução dos conflitos laborais no mundo atual. Revista do Tribunal Regional do Trabalho da 2a Região, São Paulo, SP, n. 8, p. 47-56, 2011.

VASCONCELOS, Antônio Gomes de; GOMES, Marcella Furtado de Magalhães. Mediação judicial trabalhista. Revista eletrônica [do] Tribunal Regional do Trabalho da $9^{\text {a }}$ Região, Curitiba, PR, v. 5, n. 53, p. 7-25, ago. 2016.

VIANA, Márcio Túlio. Os paradoxos da conciliação: quando a ilusão da igualdade formal esconde mais uma vez a desigualdade real. Revista do Tribunal Regional do Trabalho da 3ª Região, Belo Horizonte, MG, v. 45, n. 75, p. 185-198, jan./jun. 2007.

VIDIGAL, Márcio Flávio Salem. A conciliação no processo individual do trabalho e o art. 920, do Código Civil. Revista do Tribunal Regional do Trabalho da $3^{\text {a }}$ Região, Belo Horizonte, MG, v. 28, n. 58, p. 33-41, jan./dez. 1998.

\section{REFERÊNCIAS BIBLIOGRÁFICAS GERAIS}

AB'SÁBER, TALES Afonso Muxfeldt. Lulismo, Carisma Pop e Cultura Anticrítica. 1. ed. São Paulo: Hedra, 2011.

Dilma Roussef e o ódio político. 1. ed. São Paulo: Hedra, 2015. 
ADORNO, Theodor. "Capitalismo tardio ou sociedade industrial", In: COHN, Gabriel (org.) Theodor Adorno. Sociologia, tradução de Flávio R. Kothe, Aldo Onesti, Amélia Cohn, São Paulo: Ática, 1986.

Introdução à sociologia, tradução de Wolfgang Leo Maar, São Paulo: Editora UNESP, 2008.

Minima moralia: reflexões a paritr da vida lesada, tradução de Gabriel Cohn, Rio de Janeiro: Beco do Azougue, 2008.

ADORNO, Theodor e HORKHEIMER, Max. Temas Básicos de Sociologia. Trad. de Álvaro Cabral. São Paulo: Cultrix, 1973

AGGIO, Alberto, HENRIQUES, Luiz Sérgio e VACCA, Giuseppe (org). Gramsci no seu tempo, Tradução de Luiz Sérgio Henriques, Rio de Janeiro, Fundacao Astrojildo Pereira/Contraponto Editora 2010.

ALVES, Giovanni. O novo (e precário) mundo do trabalho: reestruturação produtiva e crise do sindicalismo. São Paulo: Boitempo, 2000.

ANTUNES, Ricardo. Adeus ao trabalho? Ensaios sobre as metamorfoses e a centralidade do mundo do trabalho, 15ª ed., São Paulo: Cortez, 2011.

ARANTES, Paulo. O novo tempo do mundo: e outros estudos sobre a era da emergência, São Paulo: Editorial Boitempo, 2014.

BATISTA, Flávio Roberto. Crítica da tecnologia dos direitos sociais. 1. ed. São Paulo: Outras expressões/Dobra editorial, 2013.

BEAUD, S. e PIALOUX, M. Rebeliões urbanas e a desestruturação das classes populares (França, 2005). Tradução de Vera Telles e revisão técnica de Sérgio Miceli. São Paulo: Revista Tempo Social, revista de sociologia da USP, v.18, n.1

Retour sur la condition ouvrière. Paris, Fayard, 1999, ed. brasileira São Paulo: Editoria Boitempo, 2009

. Violences urbaines, violence sociale. Paris, Fayard, 2003.

BECK, Ulrich. Sociedade de risco. Rumo a outra modernidade, tradução de Sebastião Nascimento, São Paulo: Editora 34, 2010 
BENJAMIN, Walter. Libro de los passajes, edição de Rolf Tiedemann, tradução para o espanhol de Luis Fernández Castañeda, Madri: 2005.

. Origem do drama trágico alemão, tradução de João Barrento, Belo Horizonte: Autêntica, 2014

Rua de mão única, tradução de Rubens Rodrigues Torres Filho e José Carlos Martins Barbosa, 6 a ed., São Paulo: Editora Brasiliense, 2012

BENSAID, Daniel. Marx: o intempestivo. Grandezas e misérias de uma aventura crítica (séculos XIX e XX), Tradução de Luiz Cavalcanti de M. Guerra, Rio de Janeiro: Civilização Brasileira, 1999

Quem é o Juiz? Para acabar com o tribunal da história, Tradução de Madalena Poole da Costa, Lisboa: Instituto Piajet, 1999.

BELLUZZO, L.G. “A transfiguração neoliberal e a construção da crise de 2008 " e " Do Estado de bem-estar às portas da barbárie”, In: O capital e suas metamorfoses, São Paulo: Editora Unesp, 2013, pp. 125-179.

BOLTANSKI, Luc e CHIAPELLO, Ève. Le nouvel esprit du capitalisme, $2^{\mathrm{a}}$ ed., Paris: Gallimard, 2011.

BIANCHI, Alvaro. O laboratório de Gramsci. Filosofia, história e política. São Paulo: Alameda, 2009.

BORCHERT, Jens e LESSENICH, Stephan. "Between the Lines of the State Theory Debate: Claus Offe's "Cheerful Eclecticism”, In: BORCHERT, Jens e LESSENICH, Stephan. Claus Offe and the Critical Theory of the Capitalist State. New York: Routledge, 2016.

BOURDIEU, Pierre. Contre-feux. Propos pour servir à la résistance contre l'invasion néo-liberale, Paris: Raisons D’Agir, 1998.

Contre-feux, 2. Pour un mouvement social européen. Paris: Raisons d'agir, 2001. . Décrire et prescrire [Note sur les conditions de possibilité et les limites de l'efficacité politique]. In: Actes de la recherche en sciences sociales. Vol. 38, mai 1981. La représentation politique-2. pp. 69-73. 
Esprits d'Etat. In: Actes de la recherche en sciences sociales. Vol. 96-97, mars 1993. pp. 49-62.

. (dir). La misère du monde, Paris: Éditions du Seuil, Edição de Bolso Points, 2007 (1993).

. La noblesse d'État. Grandes écoles et esprit de corps. Paris: Minuit, 1989.

. "Le mort saisit le vif. Les relations entre l'histoire réifiée et l'histoire incorporée". In: Actes de la recherche en sciences sociales. Vol. 32-33, avril/juin 1980. Paternalisme et maternage. pp. 3-14.

. "Les jurists, gardiens de l'hyporcrisie collective", in F. Chazel et J. Commaille (dir.), Normes Juridiques et régulation sociale, Paris, LGDJ, pp. 95-99.

Méditations Pascaliennes. Édition Revue e Corrigée. Paris: Seluil, 2003, tradução brasileira de Sérgio Miceli. Rio de Janeiro: Bertrand Brasil, 2001.

O poder simbólico. Tradução Fernando Tomaz. $16^{\mathrm{a}}$ ed. Rio de Janeiro: Bertrand Brasil, 2012.

. "Strutures, habitus et pratiques", In: Esquisse d'une théorie de la pratique, Éditions du Seuil: Paris, 2000.

. Sur l'État, Cours au Collège de France (1989-1992). Paris: Éditions Raisons d'Agir/ Éditions du Seuil, 2012.

. "Une classe objet". In: Actes de la recherche en sciences sociales. Vol. 17-18, novembre 1977. La paysannerie, une classe objet. p. 5.

BOITO JUNIOR, Armando. "A hegemonia neoliberal no governo Lula", Revista Crítica Marxista, n. 17, segundo semestre de 2003, Rio de Janeiro, Editora Revan, p. 1036

. "Governos Lula: a nova burguesia nacional no poder", In: Política e classes sociais no Brasil dos anos 2000, São Paulo: Alameda, 2012

. "O futuro do sindicalismo", In: O Sindicalismo na política brasileira, Campinas: Unicamp, Instituto de Filosofia e Ciências Humanas, 2005, pp. 297-299 
O sindicalismo na politica brasileira. 1. ed. Campinas: Instituto de Filosofia e Ciências Humanas, 2005

. Política neoliberal e sindicalismo no Brasil. 1. ed. São Paulo: Xamã Editora, 1999.

BOITO JR., Armando and BERRINGER, Tatiana. Brasil: classes sociais, "neodesenvolvimentismo" e política externa nos governos Lula e Dilma. Rev. Sociol. Polit. [online]. 2013, vol.21, n.47, pp. 31-38. ISSN 0104-4478

BOLTANSKI, Luc e CHIAPELLO, Ève. Le nouvel esprit du capitalisme, $2^{\mathrm{a}}$ ed., Paris: Gallimard, 2011.

BARROS, Alice Monteiro de. Curso de direito do trabalho, 6. ed., São Paulo : LTr, 2010

BRAGA, Ruy. A nostalgia do fordismo: modernização e crise na teoria da sociedade salarial, São Paulo: Xamã, 2003.

A política do precariado: do populismo à hegemonia lulista. 1. ed. São Paulo: Boitempo, 2012.

. A pulsão plebeia: trabalho, precariedade e rebeliões sociais. 1. ed. São Paulo: Alameda, 2015.

. "Terra em transe", In: As contradições do lulismo: a que ponto chegamos, organização André Singer e Isabel Loureiro, São Paulo; Boitempo, 2016

BRAGA, Ruy, OLIVEIRA, Francisco de, RIZEK, Cibele. Hegemonia às avessas: economia, política e cultura na era da servidão financeira, São Paulo: Boitempo, 2010

BRAVERMAN, Harry. Trabalho e capital monopolista. A degradação do trabalho no século XX. Tradução de Nathanael C. Caixeiro, $3^{\text {a }}$ ed., Rio de Janeiro: Zahar, 1980.

BÜRGER, Peter. Teoria da vanguarda. São Paulo: Cosac Naify, 2008.

CAMPOS, Antonia J.M., MEDEIROS, Jonas; RIBEIRO, Marcio. Escolas de luta, São Paulo: Veneta, 2016. 
CARDOSO, Adalberto Moreira. A construção da sociedade do trabalho no Brasil. 1. ed. Rio de Janeiro: FGV, 2010.

. A Década Neoliberal e a Crise dos Sindicatos no Brasil. 1. ed. São Paulo: Boitempo, 2003, pp. 125-126

. Uma utopia brasileira: Vargas e a construção do estado de bem-estar numa sociedade estruturalmente desigual. Dados [online]. 2010, vol.53, n.4, pp. 775-819. ISSN 1678-458

CARDOSO, Adalberto Moreira. e LAGE, Telma . As Normas e os Fatos: Desenho e Desempenho das Normas de Regulação do Mercado de Trabalho no Brasil. 1. ed. Rio de Janeiro: FGV, 2007.

CARDOSO, Fernando Henrique. Empresário Industrial e desenvolvimento econômico no Brasil, 2a ed., São Paulo: Difusão Europeia do Livro, 1972

CARONE, Edgard. "Roberto C. Simonsen e sua obra". Rev. adm. empres., São Paulo, v. 11, n. 4, p. 23-28, Dec. 1971 . Available from $<\mathrm{http}$ :/www.scielo.br/scielo.php?script=sci_arttext\&pid=S003475901971000400002\&lng=en\&nrm=iso $>$ access on 26 June 2017. http://dx.doi.org/10.1590/S0034-75901971000400002

CARVALHO, José Murilo. A construção da Ordem, $8^{\text {a }}$ ed., Rio de Janeiro: Civilização Brasileira, 2013.

CARVALHO, Laura. Valsa brasileira: Do boom ao caos econômico, São Paulo: Todavia, 2018.

CESARINO JÚNIOR, Antônio Ferreira. Direito Social, São Paulo: LTr: Ed. da Universidade São Paulo, 1980.

CEZAR PELUSO, Antônio; RICHA, Morgana de Almeida (coord.). Conciliação e mediação: estruturação da Política Judiciária Nacional, Rio de Janeiro: Forense, 2011.

CHESNAIS, François. A Mundialização do Capital, Tradução Silvana Finzi Foá, São Paulo, Xamã, 1996 
CORREIA, Marcus Orione Gonçalves (Org.) ; SOUTO MAIOR, Jorge Luiz (Org.) . Curso de direito do trabalho: direito processual do trabalho. São Paulo: LTr, 2009.

COSPITO, Giuseppe. "Egemonia", In: Le parole di Gramsci, per um lessico dei Quaderni del Carcere, Org. de Fabio Frosini e Guido Liguori, Roma: Carocci, pp. 7592 ,

COSPITO, Giuseppe. Il ritmo del pensiero, Per uma lettura diacrônica dei "Quaderni del carcere” di Gramci, Napoli,IT: Bibliopolis, 2011

COUTINHO, C.N. De Rousseau a Gramsci. São Paulo: Editorial Boitempo, 2011.

COUTINHO, Grijalbo Fernandes. O direito do trabalho flexibilizado por FHC e Lula, São Paulo: LTr, 2009 Terceirização : máquina de moer gente trabalhadora, São Paulo : LTr, 2015.

CROCE, Benedetto. Materialismo Histórico e Economia Marxista, tradução de Luis Washington, São Paulo: Centauro.

DALE, Gareth. Karl Polanyi: The Limits of the Market, Cambridge: Polity Press, 2010

ANDRADE, Daniel Pereira; OTA, Nilton Ken. Uma alternativa ao neoliberalismo: Entrevista com Pierre Dardot e Christian Laval. Tempo soc., São Paulo, v. 27, n. 1, p. 275-316, June 2015 Available from $<$ http://www.scielo.br/scielo.php?script=sci_arttext\&pid=S010320702015000100275\&lng=en\&nrm=iso $>$ access on 08 Jan. 2019. http://dx.doi.org/10.1590/0103-207020150115.

DARDOT, Pierre e LAVAL, Christian. La nouvelle raison du monde. Essai sur la société néolibérale, Paris: La Découverte, 2010.

DEBORD, Guy. La Société du Spectacle, Paris, FR: Gallimard, 1992

DE DECCA, Edgar Salvadori. 1930. O silêncio dos vencidos: memória, história e revolução, 6a ed., São Paulo: Editora Brasiliense, 1994.

DELGADO, Mauricio Godinho. Curso de direito do trabalho, 10 ed - São Pauto : LTr, 2011DIAS, Edmundo Fernandes (Org.) O outro gramsci, São Paulo: Editora Xamã, 1996 
DEUTSCH, Morton. The resolution of conflit. Construtctive and destructive processes. New Haven e Londres: Yale University Press, 1973.

DIEESE, Balanço das greves em 2013, Estudos e Pesquisas, nº 79, dezembro de 2015, disponível

https://www.dieese.org.br/balancodasgreves/2013/estPesq79balancogreves2013.pdf, consultado em 20/12/2018.

DUMÉNIL, Gérard e LÉVY, Dominique. DUMÉNIL, Gérard e DOMINIQUE Lévy. Capital Resurgent: Roots of the Neoliberal Revolution. Cambridge, MA: Harvard University Press, 2001

A crise do neoliberalismo, $1^{\mathrm{a}}$ ed., Tradução de Paulo Cesar Castanheira, São Paulo: Boitempo, 2014.

ENGELS, Friedrich. Carta para Joseph Bloch, de 21-22 de Setembro de 1890, Traduzido e anotado: por Vinicius Valentin Raduan Miguel, disponível em https://www.marxists.org/portugues/marx/1890/09/22.htm, consultado em 20/07/2017

FAUSTO, Ruy. "Dialética, estruturalismo, pré(pós)-estruturalismo", In: Dialética marxista, dialética hegeliana: a produção capitalista como circulação simples. Rio de Janeiro: Paz e Terra; São Paulo: Brasiliense, 1997.

Marx : Lógica e Política : investigações para uma reconstituição do sentido da

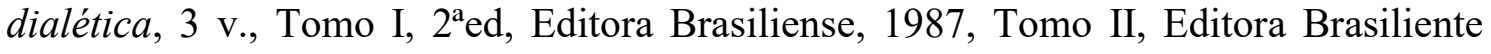
1987, Tomo III, Editora 34, 2002.

FERNANDES, Florestan. A revolução burguesa no Brasil, ensaio de interpretação sociológica, $5^{\mathrm{a}}$ ed., São Paulo: Globo, 2006

FERRIERA, Jorge. O populismo e sua história: debate e crítica, Rio de Janeiro: Civilização Brasileira, 2001).

FERREIRA, Jorge. "O nome e a coisa: o populismo na política brasileira", In: $O$ populismo e sua história: debate e crítica, Rio de Janeiro: Civilização Brasileira, 2001. 
FOOTE, Christopher, et al. "Economic Policy and Prospects in Iraq." The Journal of Economic Perspectives, vol. 18, no. 3, 2004, pp. 47-70. JSTOR, JSTOR, www.jstor.org/stable/3216806

FRANCIONI, Gianni. L'Officina gramsciana: ipottesi sulla estruttura dei "Quaderni del Carcere”, Nápoles, IT: Bibliopolis, 1984.

FRENCH, John D. Afogados em leis: a CLT e a cultura política dos trabalhadores brasileiros, tradução de Paulo Fontes, São Paulo: Editora Fundação Perseu Abramo, 2001.

FROSINI, Fabio. Ideologia em Marx e Gramsci, Educação e Filosofia Uberlândia, v. 28, n. 56, p. 559-582, jul./dez. 2014. ISSN 0102-6801.

La religione dell'uomo moderno. Politica e verità nei Quaderni del cárcere di Antonio Gramsci, Roma: Carocci, 2010.

FROSINI, Fabio e LIGUORI, Guido (Org.). Le parole di Gramsci, per um lessico dei Quaderni del Carcere, Roma: Carocci, 2004

FUKUYAMA, Francis. "The End of History?” The National Interest, no. 16, 1989, pp. 3-18. JSTOR, JSTOR, www.jstor.org/stable/24027184.

FUNDAÇÃO GETÚLIO VERGAS, OAB em números, 2016, disponível em https://bibliotecadigital.fgv.br/dspace/bitstream/handle/10438/18493/oab 3 edicao v4 web espelhado.pdf, consulta em 27.12.2018

GALASTRI, Leandro. Gramsci, marxismo e revisionismo, Campinas: Editores associados, 2015.

GALVÃO, Andréia. Neoliberalismo e reforma trabalhista no Brasil. Rio de Janeiro: Revan, 2007.

GIGLIO, Wagner. Conciliação nos dissídios individuais do trabalho, Porto Alegre: Síntese, 1997,

GLYN A., HUGHES A., SINGH A. "The Rise And Fall Of The Golden Age", In: The Golden Age of Capitalism, Clarendon-Oxford UP, Oxford 1990. 
GOMES, Ângela de Castro. Burguesia e trabalho, politica e legislação social no Brasil (1917-1937), $2^{a}$ edição, São Paulo: Editora 7 Letras,

- "O populismo e as ciências sociais no brasil: notas sobre a trajetória de um conceito", In: O populismo e sua história: debate e crítica, Rio de Janeiro: Civilização Brasileira, 2001, pp. 17-57.

GRAMSCI. A. Quaderni del Carcere. Edição Crítica do Instituto Gramsci de Valentino Gerratana, Torino: Eiunaudi, 1977.

HABERMAS, Jürgen. Crise De Legitimação No Capitalismo Tardio, tradução de Lucia Aragão. Rio de Janeiro: Tempo Brasileiro, 2002.

HARVEY, David. A condição pós moderna - Uma pesquisa sobre as Origens da Mudança Cultural, Tradução de Adail Ubirajara Sobral e Maria Stela Gonçalves, 25 ed., São Paulo: Edições Loyola, 2014.

. O Enigma do Capital: e as crises do capitalismo. Tradução de João Alexandre Peschanski. São Paulo, SP: Boitempo, 2011

. O Neoliberalismo: História e Implicações. São Paulo, Edições Loyola, 2008.

O novo imperialismo, tradução: Adail Sobral e Maria Stela Gonçalves, São Paulo: Edições Loyola, 2004

Os limites do capital, tradução de Magda Lopes, São Paulo: Boitempo, 2013.

HEIDEGGER, Martin. Ser y Tiempo, tradução de Jorge Eduardo Rivera, Madrid: Trotta 2003

HILLESHEIM, Jaime. Conciliação trabalhista: ofensiva sobre os direitos dos trabalhadores na periferia do capitalismo, Rio de Janeiro: Lumen Juris, 2016

KLEIN, Naomi. A doutrina do choque: a ascensão do capitalismo de desastre, tradução Vania Cury. - Rio de Janeiro: Nova Fronteira, 2008.

KOJÈVE, Alexandre. Introdução à leitura de Hegel, tradução de Estela dos Santos Abreu, Rio de Janeiro: Contraponto, 2002. 
KURZ, R. O colapso da modernização. Da derrocada do socialismo de caserna à crise econômica mundial, tradução Karen Elsabe Barbosa, 2a ed., Rio de Janeiro: Paz e Terra, 1992.

LACCORTE, Rocco. "Sobre alguns aspectos da "tradutibilidade" nos cadernos do cárcere de Antonio Gramsci e algumas das suas implicações”, In: Educação e Filosofia Uberlândia, v. 28, n. 55, p. 59-98, jan./jun. 2014. ISSN 0102-6801, doi: http://dx.doi.org/10.14393/REVEDFIL.issn.0102-6801.v28n55a2014-p59-98.

LEVY, Paulo Mansur. "Inflação crônica, estagnação e instabilidade: o difícil caminho até a estabilização (1987-1994)", In: Economia brasileira no período 1987-2013 : relatos e interpretações da análise de conjuntura no Ipea / organizador: Fernando José da S. P. Ribeiro ; Estêvão Kopschitz Xavier Bastos ... [et al.]. - Brasília :IPEA, 2015, disponível em http://www.ipea.gov.br/portal/images/stories/PDFs/livros/livros/151218 livro_economi a brasilera.pdf, consultado em 20/07/2019

LIGUORI, Guido. Gramsci conteso. Interprestazioni, dibattiti e polemiche 1922-2012, edição ampliada, Roma: Editori Riuniti Univesity Press, 2012

. Roteiros para Gramsci, tradução de Luiz Sérgio Henriques, Rio de Janeiro: Editora UFRJ, 2007.

LIGUORI, Guido e PASQUALE, Voza (Org.). Dizionario Gramsciano : 1926-1937, Roma : Carocci, 2011, também disponível online no "Gramsci Project", http://dizionario.gramsciproject.org/, acessado em 07 de Outubro de 2015.

LOPREATO, Christina da Silva Roquette. O espírito da revolta (a greve geral anarquista de 1917), tese de Doutorado - Universidade Estadual de Campinas, Instituto de Filosofia e Ciências Humanas, 1996.

LOWY, Michel. A jaula de aço. Max Weber e o marxismo weberiano, tradução Mariana Echalar, São Paulo: Boitempo, 2014. . Método Dialético e Teoria Política, Tradução de Reginaldo di Piero, Rio de Janeiro: Paz e Terra, 1975 
- Política de desenvolvimento desigual e combinado: a teoria da revolução permanente, tradução de Luiz Gustavo Soares, São Paulo: Sundermann, 2015.

LOWY, Michel e SAYRE, Robert. Revolta e melancolia. O Romantismo na contracorrente da modernidade, tradução de Nair Fonseca, São Paulo: Boitempo Editorial, 2015.

LUHMANN, Niklas. La sociedad de la sociedade, tradução de Javier Nafarrate, Cidade do México : Herder, 2007.

. Legitimidade pelo Procedimento, UnB; Brasília: 1980.

. Sociologia do direito, tradução de Gustavo Bayer. 1, São Paulo: Tempo Brasileiro, 1983

LUKÁCS, G. Geschichte und Klassenbewusstsein. Studien über marxistische dialektik, Werke Band 2. Darmstadt: Luchterhand, tradução brasileira citada, História $e$ Consciência de Classe. Estudos sobre a dialética marxista. Tradução de Rodnei Nascimento, $2^{\mathrm{a}}$ ed., São Paulo: Editora WMF Martins Fontes, 2012.

LUXEMBURGO, Rosa. A acumulação de capital: contribuição ao estudo econômico do Imperialismo, tradução de Marijane Vieira Lisboa, 2a ed., São Paulo: Nova Cultural, 1985

MACABELLI, Terenzio. “A grande transformação': as reações entre Estado e economia nos 'Cadernos do Cárcere”, In: AGGIO, Alberto, HENRIQUES, Luiz Sérgio e VACCA, Giuseppe (org). Gramsci no seu tempo, Tradução de Luiz Sérgio Henriques, Rio de Janeiro, Fundacao Astrojildo Pereira/Contraponto Editora 2010.

MALAN, Pedro. Uma crítica ao Consenso de Washington. Revista de Economia Política, v. 11, n. 3, julho-setembro de 1991.

MANDEL, Ernest. A crise do Capital. Os fatos e sua interpretação marxista, tradução de Juarez Guimarães e João Machado Borges, São Paulo: Ensaio, 1990.

MARAN, Sheldon Leslie. Anarquistas, imigrantes e o movimento operário brasileiro (1890-1920), Rio de Janeiro: Paz e Terra, 1979 
MARCUSE, H. Razão e revolução: Hegel e o advento da teoria social. Tradução de Marília Barroso, 2aed. Rio de Janeiro: Paz e Terra, 1978.

MARINI, Ruy Mauro. "Movimento Revolucionário Brasileiro", In: Subdesenvolvimento e revolução, tradução de Fernando Correa Prado e Marina Machado Gouvêa, Florianópolis: Editora Insular, 2017

MARQUES, Rosa Maria; MENDES, Áquilas. O governo Lula e a contra-reforma previdenciária. São Paulo Perspec., São Paulo , v. 18, n. 3, p. 3-15, Sept. 2004. Available from $\quad<$ http://www.scielo.br/scielo.php?script=sci_arttext\&pid=S010288392004000300002\&lng=en\&nrm=iso $>$ access on $24 \quad$ Dec. 2018. http://dx.doi.org/10.1590/S0102-88392004000300002.

MARX, Karl. A ideologia alemã: crítica da mais recente filosofia alemã em seus representantes, Feuerbach, B.Bauer e Stirner, e do socialismo alemão em seus diferentes profetas (1845-18460), Tradução de Rubens Enderle, Nélio Schneider e Luciano Cavini, Martorano, São Paulo: Boitempo, 2007.

A guerra civil na França"", In: A revolução antes da revolução, v. 2, São Paulo: Expressão Popular 2008.

. "As lutas de classes na França", In: A revolução antes da revolução, v. 2, São Paulo: Expressão Popular 2008.

. Crítica da filosofia do direito de Hegel, 1843, Tradução de Rubens Enderle e Leonardo de Deus, 2a ed., São Paulo: Boitempo, 2010.

- Crítica do Programa de Gotha, Tradução de Rubens Enderle, São Paulo: Boitempo: 2012.

. Grundrisse : manuscritos econômicos de 1857-1858: esboços da crítica da economia política. Tradução de Mario Duayer. Boitempo, 2011.

. "O 18 brumário de Luís Bonaparte", In: A revolução antes da revolução, v. 2, São Paulo: Expressão Popular 2008.

O capital: crítica da economia política. Tradução de Regis Barbosa e Flávio R. Kothe, $2^{\text {a }}$ ed., São Paulo: Nova Cultural, 1985. 
. Manifesto Comunista, tradução de Álvaro Pina, São Paulo: Boitempo, 2007

- Manuscritos econômico-filosóficos, Tradução de Jesus Ranieri, São Paulo: Boitempo, 2010.

- "Prefácio", In: Para a crítica da economia política, tradução de Edgard Malagodi, São Paulo: Abril Cultura, 1992

. Sobre a questão judaica, Tradução de Nélio Schneider, São Paulo: Boitempo, 2010 .

MARX, Karl e ENGELS, Friedrich. A sagrada família, ou a crítica da Crítica crítica contra Bruno Bauer e consortes, Tradução de Marcelo Backes, São Paulo: Boitempo, 2011.

Lutas de classe na Rússia, Org. Michael Löwy, Tradução de Nélio Schneider, São Paulo: Boitempo, 2013.

MAINE, Henry James Sumner. Ancient Law, its Connection with the Early History of Society, and its Relation to Modern Ideas. Tucson, Arizona: The University of Arizona Press, 1986.

MELO, Frederico Luiz Barbosa (org). Salário Mínimo no Brasil: a luta pela valorização do trabalho, São Paulo: LTr, 2015.

MORA, Mônica. A evolução do crédito no Brasil entre 2003 e 2010. Texto para discussão / Instituto de Pesquisa Econômica Aplicada.- Brasília : Rio de Janeiro : Ipea

MORAES, Germana de Oliveira e LORENZONI, Eduardo Kurtz. "A bandeira da paz na Justiça Brasileira (Nascimento, Berço e Vida durante a Gestão Inicial do CNJ”, In: CEZAR PELUSO, Antônio; RICHA, Morgana de Almeida (coord.). Conciliação e mediação: estruturação da Política Judiciária Nacional. Rio de Janeiro: Forense, 2011

MUÑOZ, Alberto Alonso. Modelos de fundamentação filosófica do direito privado e seus limites: contribuição à crítica do direito privado. 2015. Tese (Doutorado em Filosofia e Teoria Geral do Direito) - Faculdade de Direito, Universidade de São Paulo, São Paulo, 2015. doi:10.11606/T.2.2015.tde-17082015-205138. Acesso em: 2017-06-26 
NASCIMENTO, Amauri Mascaro. Curso de direito do trabalho : história e teoria geral do direito do trabalho : relações individuais e coletivas do trabalho , 26. ed. - São Paulo : Saraiva, 2011

OFFE, Claus. Problemas estruturais do Estado capitalista. Tradução de Bárbara Freitag. Rio de Janeiro: Tempo Brasileiro, 1984.

OLIVEIRA, Francisco de. Brasil. Uma Biografia não Autorizada, São Paulo: Boitempo, 2018

. Collor, a falsificação da ira, Rio de Janiero: Imago, 1992.

. Crítica à razão dualista/O ornitorrinco. São Paulo, Boitempo, 2003.

. "Elegia para uma re(li)gião", In: Noiva da revolução; Elegia para uma re(li)gião: Sudene, Nordeste. Planejamento e conflito de classes, São Paulo: Boitempo, 2008

. Os direitos do anti-valor: a economia política da hegemonia imperfeita. Petrópolis: Vozes, 1985

PACHUKANIS, Erwin. A teoria geral do direito e o marxismo, Tradução de Soveral Martins, Coimbra: Centelha Editorial, 1977.

PARANHOS, A. O roubo da fala: as origens da ideologia do trabalhismo no Brasil, p. 17 e ALBERTINO, José. Sindicato e desenvolvimento no Brasil, $2^{\text {a }}$ ed., São Paulo: Edições Símbolo, 1979.

PAULANI, Leda. Brasil delivery : servidão financeira e estado de emergência econômico, Boitempo: São Paulo, 2008

PELUSO, Antonio Cezar e RICHA, Morgana de Almeida. Conciliação e mediação: estruturação da política nacional, Rio de Janeiro: Editora Forense, 2008

PEREIRA, José Luciano de Castilho. "Formação de Magistrados: o Brasil e a Escola Nacional de formação e aperfeiçoamento de magistrados do trabalho", In: Conciliação Judicial Individual e Coletiva e Formas Extrajudiciais de solução dos conflitos trabalhistas: homenagem ao Ministro Antonio de Barros Levenhagen, São Paulo: LTr, 2014. 
PICHLER, Walter Arno. “1989: uma conjuntura marcada pelas greves”, Revista FEE, v. 17, n 4, pp. 176-189, ISSN 1806-8987.

PIERUCCI, Antônio Flávio. O desencantamento do mundo: todos ao passos do conceito em Max Weber. São Paulo: USP, Curso de Pós-Graduação em Sociologia/Ed. 34, 2003

PIKETTY, Thomas. O capital no século XXI, Tradução: Monica Baumgarten de Bolle, Rio de Janeiro: Intrínseca, 2014, edição digital.

PLÁ RODRIGUES, Americo. Princípios do direito do trabalho, tradução de Edilson Alkmim Cunha, revisão de Wagner Gilgio, $3^{\text {a }}$ ed., São Paulo: LTr, 2015

POCHMANN, Márcio. . A superterceirização do trabalho, São Paulo: LTr, 2008. . Nova Classe Média? O trabalho na base da pirâmide social brasileira. 1. ed. São Paulo: São Paulo, 2012. . O mito da grande classe média. 1. ed. São Paulo: Boitempo, 2014.

POLANYI, Karl. A grande transformação, $2^{\mathrm{a}}$ ed., Tradução de Fanny Wrobel, Rio de Janeiro: Ed. Campus, 2000.

POULANTZAS, Nicos. Hegemonia y Dominacion em el Estado Moderno, Tradução de María T. Poyarazián. Còrdoba: Ediciones Pasado y Presente, 1969.

. Poder político e classes sociais. Tradução de Francisco Silva, São Paulo: Martins Fontes, 1977. O Estado, o Poder e o socialismo, $4^{\text {a }}$ ed., Tradução de Rita Lima, São Paulo: Paz e Terra/Graal, 2000.

PRESTIPINO, Giuseppe. "Dialettica", In: Le parole di Gramsci, per um lessico dei Quaderni del Carcere, Org. de Fabio Frosini e Guido Liguori, Roma: Carocci, pp. 55-73 RODRIGUES, Iram Jácome. Sindicalismo e política. A trajetória da CUT (1983-1993), $2^{\mathrm{a}}$ ed. revista, São Paulo: LTr, 2011.

RODRIGUES, José Albertino. Sindicato e desenvolvimento no Brasil, $2^{\mathrm{a}}$ ed., São Paulo: Símbolo, 1978. 
SAAD-FILHO, Alfredo. "From Whashington to Post-Washington Consensus: Neoliberal Agendas for Economic Development", In: Neoliberalism. A critical reader, Londre: Pluto Press, 2005.

. "The Political Economy of Neoliberalism in Latin America", In: Neoliberalism. A critical reader, Londre: Pluto Press, 2005

SADEK, Maria Tereza. "A crise do judiciário vista pelos juízes: resultados de uma pesquisa quantitativa", In: Uma introdução ao estudo da justiça [online]. Rio de Janeiro: Centro Edelstein de Pesquisas Sociais, 2010.. pp. 17-31. ISBN: 978-85-7982$032-8$

. "Controle externo no Poder Judiciário", In: Reforma do judiciário . São Paulo: Fundação Konrad Adenauer, 2001

• "Introdução", In: Reforma do judiciário . São Paulo: Fundação Konrad Adenauer, 2001, pp. 7-21.

. Judiciário: mudanças e reformas. Estud. av., São Paulo , v. 18, n. 51, p. 79101, Aug. 2004 Available from $<$ http://www.scielo.br/scielo.php?script=sci_arttext\&pid=S010340142004000200005\&lng=en\&nrm=iso $>$. access on 27 June 2017. http://dx.doi.org/10.1590/S0103-40142004000200005 Poder Judiciário: Perspectivas de Reforma. Opinião Pública, Campinas, SP, v. 10, n. 1, p. 1-62, out. 2015. ISSN 1807-0191. Disponível em: $<$ https://periodicos.sbu.unicamp.br/ojs/index.php/op/article/view/8641138>. Acesso em: 27 dez. 2018.

SAMPAIO JR., Plínio de Arruda. Crônica de uma crise anunciada: crítica da economia política de Lula e Dilma: SG-Amarante Editorial, 2017.

Globalização e reversão neocolonial: o impasse brasileiro. En publicación: Filosofía y teorías políticas entre la crítica y la utopía. Hoyos Vásquez, Guillermo. CLACSO, Consejo Latinoamericano de Ciencias Sociales, Buenos Aires. 2007. ISBN: 978-987-1183-75-3

SCHIAVI, Mauro. Manual de Direito Processual do Trabalho, $7^{\text {a }}$ ed., 2014 
SECCO, Lincoln. História do PT, 2 ed. 2. ed. São Paulo: Ateliê, 2011.

SENA, Adriana Goulart e OLSON, Giovanni. "Técnicas do Juízo Conciliatório na Justiça do Trabalho", In: Conciliação e mediação: estruturação da Política Judiciária Nacional. Rio de Janeiro: Forense, 2011

SILVA, Homero Batista Mateus da. Curso de direito do trabalho aplicado [livro eletrônico]: justiça do trabalho, $1^{\text {a }}$ ed., São Paulo: Editora Revista dos Tribunais, 2015.

SILVA, Fernando Teixeira. Trabalhadores no tribunal,: conflitos e Justiça do Trabalho em São Paulo no contexto do Golpe de 1964, São Paulo: Alameda, 2016

SIMÃO, Azis. Sindicato e Estado: suas relações na formação do proletariado de São Paulo, $3^{\text {a }}$ ed. - São Paulo: Hucitec, 2012

SIMONSEN, Roberto. "Evolução industrial do Brasil", In: Evolução Industrial do Brasil e outros estudos, seleção notas e bibliografia de Edgard Carone São Paulo: Eidotra Nacional e Editora da USP, 1972

SINGER, André Vitor. Esquerda e direita no eleitorado brasileiro, São Paulo: Editora da Universidade de São Paulo, 2000.

Os sentidos do lulismo. Reforma gradual e pacto conservador. 1. ed. São Paulo: Companhia das Letras, 2012.

SOARES, Laura Tavares. Os custos sociais do ajuste neoliberal na América Latina, $2^{\mathrm{a}}$ ed., São Paulo: Cortez, 2002.

SOMBART, Werner. El apogeo del capitalismo, V.1,tradução de José Urbano Guerrero, México : FCE, 1946.

SOREL, Georges. Reflexões sobre a violência, tradução de Paulo Neves, São Paulo: Martins Fontes, 1992.

SOUTO MAIOR, Jorge Luiz. Conflitos do trabalho: comissões de conciliação prévia. 2002. (Apresentação de Trabalho/Simpósio), Disponível em: http://www.jorgesoutomaior.com/uploads/5/3/9/1/53916439/conflitos do trabalho.pdf, acessado em 07/10/15. 
. Curso de Direito do Trabalho: teoria geral do direito do trabalho, V.1, Parte I, São Paulo: LTr, 2011

- "Efeitos da Emenda constitucional n. 24/99 e as armadilhas das recentes reformas trabalhistas", In: Revista do Tribunal Regional do Trabalho da 15a Região, Campinas, SP, n. 11, p. 41-46, abr./jun. 2000.

História do direito do trabalho no Brasil: curso de direito do trabalho, vol. I: parte II, São Paulo: LTr, 2017.

- Impactos do golpe trabalhista (a Lei n. 13.467/17), disponível em https://www.jorgesoutomaior.com/blog/impactos-do-golpe-trabalhista-a-lei-n-1346717, consultado em 13.01.2019.

Temas de processo do trabalho. São Paulo: LTr, 2000

- Velhas e novas ameaças do neoliberalismo aos direitos trabalhistas, http://www.migalhas.com.br/arquivos/2015/1/art20150102-04.pdf, acessado em 07/10/2015.

SOUZA, Jessé . Os Batalhadores brasileiros: nova classe média ou nova classe trabalhadora? 2 edição ampliada e revista. 2. ed. Belo Horizonte: UFMG, 2012. . A Ralé Brasileira: quem é e como vive, Belo Horizonte: UFMG, 2009.

STIGLITZ, Joseph. Os exuberantes anos 90. Uma nova interpretação da década mais próspera da história, tradução de Sylvia Maria S. Cristóvão dos Santos, Dante mendes Aldrihi, José Francisco de Lima Gonçalves, Roberto Mazzer Neto, São Paulo: Companhia das Letras, 2003.

STUTCHKA, Piotr. "Direito Proletário", In: Direito de Classe e revolução socialista, tradução de Emil von München, $3^{\text {a }}$ ed., Editora Sundermann,2009

TOLEDO, Edilene. Travessias revolucionárias: ideias e militantes sindicalistas em São Paulo e na Itália (1890-1945), Campinas, SP: Editora da Unicamp, 2004.

TRIBUNAL SUPERIOR DO TRABALHO, Coordenadoria de Estatístuca e Pesquisa do TST. Relatório Geral da Justiça do Trabalho 2016, pp. 108-109, Disponível em: 
http://www.tst.jus.br/documents/18640430/5a3b42d9-8dde-7d80-22dd-d0729b5de250, acesso em 20/12/2018.

TROTSKY, Leon. A teoria da revolução permanente, tradução de Diego Siqueira e Hermínio Sacchetta e João Galvão, São Paulo: Editora Instituto José Luís e Rosa Sundermann, 2010.

. História da Revolução Russa, tradução de Diego Siqueira São Paulo: Editora Instituto José Luís e Rosa Sundermann, 2v., 2007.

- Questões do modo de vida. A moral deles e a nossa, tradução de Diego Siqueira

e Daniel Oliveira, São Paulo: Editora instituto José Luis e Rosa Sundarman, 2009

- Revolução passiva e modo de vida: ensaios sobre as classes subalternas, o capitalismo e a hegemonia. São Paulo: Editora Sundermann, 2012.

VIANNA, Oliveira. Populações meridionais do Brasil, Senado Federal, Conselho Editorial, 2005

VIANNA, Segadas. "Antecedentes Históricos”, In: Instituições de direito do trabalho, 15ª ed., São Paulo: LTr, 1995

VACCA, Giuseppe. Vida e pensamento de Antonio Gramsci: 1926-1937, tradução de Luiz Sérgio Henriques, Rio de Janeiro: Editra Contraponto, 2012

VIEIRA, Evaldo. Autoritarismo e corporativismo no Brasil, $3^{\mathrm{a}}$ ed., São Paulo: Editora Unesp, 2010

VILLAS BÔAS FILHO, Orlando. Juridicidade: uma abordagem crítica à monolatria jurídica como obstáculo epistemológico. Revista da Faculdade de Direito da Universidade de São Paulo, São Paulo, v. 109, p. 281-325, jan./dez. 2014.

VILLAS BÔAS FILHO, Orlando. A regulação jurídica para além de sua forma ocidental de expressão: uma abordagem a partir de Étienne Le Roy. Revista Direito \& Práxis, Rio de Janeiro, v. 6, n. 12, p. 159-195, jul./dez. 2015.

VOZA, Pasquale. "Revolução Passiva", In: Dicionário Gramsciano (1926-1937), tradução de Ana Maria Chiarini, Diego Silveira Coelho Ferreira, Leandor de Oliveira 
Galastri e Silva De Bernardinis, revisão técnica de Marco Aurelio Nogueira, São Paulo: Boitempo, 2017

. "Rivoluzione Passiva", In: Le parole di Gramsci, per um lessico dei Quaderni del Carcere, Org. de Fabio Frosini e Guido Liguori, Roma: Carocci, pp. 189-207

WATANABE, Kazuo. "Política Pública do Poder Judiciário Nacional para Tratamento Adequado dos Conflitos de Interesse”, In: CEZAR PELUSO, Antônio; RICHA, Morgana de Almeida (coord.). Conciliação e mediação: estruturação da Política Judiciária Nacional. Rio de Janeiro: Forense, 2011

WEBER, Max. A ética protestante e o "espirito" do capitalismo, tradução de José Marcos Mariani de Macedo, São Paulo: Companhia das letras, 2004.

WEFFORT, Francisco C. O populismo na política brasileira. 5. ed. Rio de Janeiro: Paz e Terra, 2003.

WEINSTEIN, Barbara. (Re)formação da classe trabalhadora no Brasil (1920-1964), tradução de Luciano Vieira Machado, São Paulo: Cortez, 2000.

WERNECK VIANA, Luiz. Liberalismo e Sindicato no Brasil, 4ª ed. revisada, Belo Horizonte: UFMG, 1999

WILliAMSON, John. Depois do Consenso de Washington: Uma Agenda para Reforma Econômica na América Latinal, palestra disponibilizada em https://piie.com/publications/papers/williamson0803.pdf, consultado em 16/12/2018.

ŽIŽEK, Slavoj. Problema no paraíso: do fim da história ao fim do capitalismo, tradução Carlos Alberto Medeiros, Rio de Janeiro: Zahar, 2015, edição digital. 